\title{
The International Monetary
}

Fund: $\mathbf{7 0}$ Years of Reinvention

Faculty Research Working Paper Series

\section{Carmen Reinhart}

Harvard Kennedy School

\section{Christoph Trebesch}

University of Munich

\section{December 2015}

\section{RWP15-077}

Visit the HKS Faculty Research Working Paper Series at:

https://research.hks.harvard.edu/publications/workingpapers/Index.aspx

The views expressed in the HKS Faculty Research Working Paper Series are those of the author(s) and do not necessarily reflect those of the John F. Kennedy School of Government or of Harvard University. Faculty Research Working Papers have not undergone formal review and approval. Such papers are included in this series to elicit feedback and to encourage debate on important public policy challenges. Copyright belongs to the author(s). Papers may be downloaded for personal use only. 


\title{
Acknowledgements
}

This paper was prepared for the Journal of Economic Perspectives. The authors wish to thank Aitor Erce, Gordon Hanson, Enrico Moretti, Vincent Reinhart, Kenneth Rogoff, Timothy Taylor, and Lena Thurau for helpful comments. Maximilian Mandl and Maximilian Rupps provided excellent research assistance.

The views expressed herein are those of the authors and do not necessarily reflect the views of the Harvard Kennedy School or the National Bureau of Economic Research.

(C) 2015 by Carmen M. Reinhart and Christoph Trebesch. All rights reserved. Short sections of text, not to exceed two paragraphs, may be quoted without explicit permission provided that full credit, including (C) notice, is given to the source.

\begin{abstract}
$\underline{\text { Abstract }}$
A sketch of the International Monetary Fund's 70-year history reveals an institution that has reinvented itself over time along multiple dimensions. This history is primarily consistent with a "demand driven" theory of institutional change, as the needs of its clients and the type of crisis changed substantially over time. Some deceptively "new" IMF activities are not entirely new. Before emerging market economies dominated IMF programs, advanced economies were its earliest (and largest) clients through the 1970s. While currency problems were the dominant trigger of IMF involvement in the earlier decades, banking crises and sovereign defaults became they key focus since the 1980s. Around this time, the IMF shifted from providing relatively brief (and comparatively modest) balance-of-payments support in the era of fixed exchange rates to coping with more chronic debt sustainability problems that emerged with force in the developing nations and now migrated to advanced ones. As a consequence, the IMF has engaged in "serial lending", with programs often spanning decades. Moreover, the institution faces a growing risk of lending into insolvency, most widespread among low income countries in chronic arrears to the official sector, but most evident in the case of Greece since 2010. We conclude that these practices impair the IMF's role as an international lender of last resort.
\end{abstract}




\section{Intoduction}

As recently as 2008, the International Monetary Fund (IMF) seemed to be winding down its business. After the Argentine and Uruguayan crises of 2001-2003, the world had been comparatively free of financial crises. IMF lending, whether expressed as a share of world GDP or imports, fell to its lowest levels since the early 1970s, as shown in Figure 1. Dollar amounts declined more markedly than the number of programs, as lending to the larger emerging markets and middle income countries mostly came to an end. Low income countries (involving smaller dollar amounts) became increasingly overrepresented among the remaining programs.

A view emerged that perhaps an institution whose primary roles were economic surveillance and crisis management had outlived its usefulness. Possibly, this interpretation of events motivated the IMF to downsize (Gourinchas and Obstfeld 2012). Treating this temporary calm as the "new normal," the IMF shrank the size of its staff, which had expanded considerably in previous decades in response to a sharp increase in its membership (as reported, for example, in the Economist 2008).

However, the emergence in 2007-2009 of the deepest and most synchronous financial crisis in the world's largest economies since the 1930s put an end to the notion that the IMF was redundant. As Kindelberger (1978) had wisely observed decades earlier, “Financial crises are a hardy perennial.” By practically any metric, the post-2008 IMF programs to several European economies are the largest in the IMF's 70-year history. As Figure 1 shows, the new programs to the wealthier borrowers brought total IMF commitments in 2010 (as a share of imports) close to its historical peak in the early 2000s, while as a share of world GDP, IMF commitments hit an all-time peak.

The IMF has reinvented itself on several occasions and in different dimensions since its creation approximately 70 years ago. ${ }^{1}$ Under the Bretton Woods system, the IMF oversaw a network of mutually pegged exchange rates. A key challenge of that system was to get the parity "right.” Otherwise, an

\footnotetext{
${ }^{1}$ Excellent companion studies to this paper include Edwards (1989) and Bordo and James (2000), who together provide a concise picture of what the IMF does that is also rich in historical detail. Further important pieces on the IMF's history and mission include Horsefield et al. (1969), De Vries et al. (1976), Nowzad (1981), Boughton and Lateeef (1995), Krueger (1998), and Boughton (2001, 2012). Appendix I provides a brief discussion of how IMF quotas are determined and the relationship between quotas and lending.
} 
economy with an overvalued currency would be vulnerable to a weakening in the balance of payments and international reserve losses.

Figure 1. IMF Lending as a share of World Trade and GDP, 1960-2014

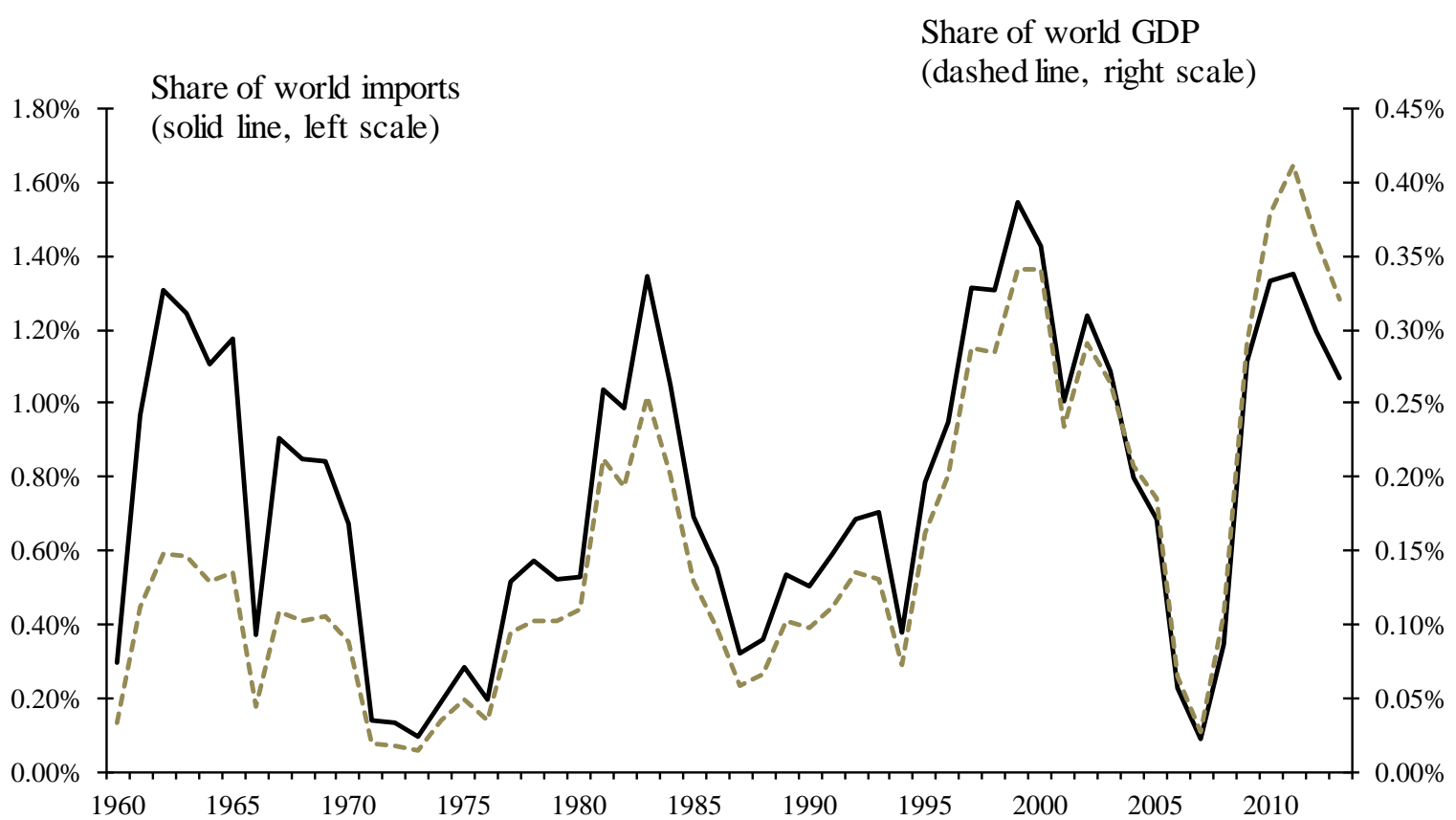

Sources: Gold (1970), International Monetary Fund, International Financial Statistics, Monitoring of Fund Arrangements (MONA) Database, World Economic Outlook, Joyce (2005), Killick (1995), and Mody and Saravia (2006).

Because exchange rate misalignments and corresponding balance-of-payments problems were a frequent and recurrent preoccupation among the IMF membership, the so-called Stand-By Arrangements of the earlier era involved short-term lending to deal with temporary (illiquidity) problems. This mandate is laid out in section I (v) of the Articles of Agreement of the IMF, which reads: "To give confidence to members by making the general resources of the Fund temporarily available to them under adequate safeguards, thus providing them with opportunity to correct maladjustments in their balance of payments without resorting to measures destructive of national or international prosperity.” From this perspective, the IMF was not intended to function as a development agency engaged in long-term lending (this was a role assigned of the World Bank and various regional development agencies). Nor was it an institution to lend into situations of sovereign insolvency. Its intended mandate was to act as the international lender of last resort. 
During the 1950s and 1960s, IMF lending had, indeed, been mostly short-term loans to the governments of advanced economies in connection with comparatively moderate exchange-rate adjustments. But the global Bretton Woods system of pegged exchange rates came apart by the early 1970s and some of the world's major economies adopted floating exchange rates. ${ }^{2}$ The role of the IMF began to evolve. At this time, the membership of the IMF also expanded significantly to include a growing number of low-income and middle-income countries. Starting in the late 1970s, the IMF programs increasingly involved lending to countries with a wider range of crises (apart from those related to foreign exchange), including banking, and sovereign debt crises. IMF lending in these gained ground with the Latin American crisis of the 1980s and the over-borrowing of many transition economies (formerly connected to the Soviet Union) in the 1990s. As banking and debt crises tend to be much more protracted problems compared to the currency crises of the earlier decades, the average duration of IMF involvements increased markedly. Chronic and recurrent IMF clients multiplied and program duration has sometimes spanned more than 20 years. ${ }^{3}$ Thus, IMF programs came to have less to do with the original mission of providing temporary liquidity support, and began to resemble longterm development assistance, especially in some of its poorest member countries.

Since the short-lived lull in the years leading up 2007, the IMF has (once again) redefined its role, making extremely large loans (relative to the size of the national economies) to wealthy economies in Europe, with the largest of these to Greece, where debt sustainability problems have been manifest for some years now. In some sense, this most recent change brings the IMF full circle, because advanced economies had been its earliest and largest clients before the emerging markets economies started to dominate its activity in the 1980s.

In what follows, we discuss the evolution of the IMF during the past 70 years from several angles. Our narrative documents the evolving “clientele” for IMF programs and provides a sense of how activity shifted across different parts of the globe and between advanced and emerging economies. We

\footnotetext{
${ }^{2}$ See https://www.imf.org/external/about/histend.htm.

${ }^{3}$ The IMF (2002), Bird et al. (2004), Joyce (2005), and Mody and Saravia (2006), all figure prominently among the studies that have addressed the causes and consequences behind the protracted duration of Fund programs or their recurring "serial” nature. Bulow and Rogoff (1990) and (2005) discuss alternative approaches to address the sustained financing needs of low income countries.
} 
connect some of these shifts to the ascendancy of financial liberalization and the subsequent increase in cross border finance, as well as global factors such as international interest rates, primary commodity prices, and global saving patterns. We also consider how the situations to which the IMF responds to has changed over time, from the early focus on currency problems to the more engulfing challenges posed by systemic banking and sovereign debt crises, often involving protracted output slumps and large-scale bailouts of the corporate and banking sectors.

Our approach concentrates on the fundamental changes in the IMF's borrowing patterns rather than delving into concerns about how particular crisis episodes were handled. On the latter, there is a substantive body of literature which critiques IMF practices. One strand of this literature focuses on the prominent role of political influence (most notably by the United States) on the design and incidence of IMF programs. Another body of work takes issue with various aspects of IMF conditionality (including the role of fiscal austerity). While we refer to relevant works in these areas, we take a different perspective.

We focus, in particular, on the IMF's role in the international financial architecture and the problems arising from "serial” IMF lending and from lending to countries with excessive debt burdens. We suggest that the changing nature of lending patterns over time has left the IMF with conflicting objectives. In dealing with potentially unsustainable debt cases and in moving toward larger and longer term loan packages, the institution has become more involved in lending into sovereign default (often chronic). An important unintended consequence of this tilt towards lending into arrears, is that a country that seeks an IMF loan may be inadvertently signaling to the rest of the world that it is insolvent (and not just illiquid). Indeed, a recent IMF (2014a, p. 4) report recognized that there is a large "stigma associated with using Fund resources.” The financial press (e.g. The Economist 2009) has been aware of this issue for some time.

The adverse signaling effect has potentially damaging consequences for the IMF's role as a lender of last resort in crisis times, notably if solvent countries in need of liquidity refrain from approaching the IMF altogether. While there are numerous development banks, the IMF is the one 
institution that is sometimes described as a central bank for countries or lender of last resort to the world (for example the essays in Bank of International Settlements: BIS 2014). The Fund could better fulfil its mandate if it drew a clearer line between members that need financing for temporary balance-ofpayments or liquidity problems, and countries that show a chronic dependence on concessionary external funds. At the end of the paper, we offer some speculation on the direction and dimension of the next wave of changes that the IMF may confront.

\section{Shifting Clientele}

When viewed by the number of its members, the IMF is a very successful institution. The initial membership of 28 back in 1945 has increased steadily to 188 in 2015 (Figure 2) with two notable growth spurts: a jump of 33 countries in the early 1960s, as the former colonies in Africa gained independence, and a jump of 28 countries in the early 1990s after breakdown of the Soviet Union. ${ }^{4}$ New entrants often asked for IMF assistance shortly after becoming members, which partly explains why the number and countries with an IMF program has increased so markedly in the early 1960s, as shown in Figure 3.

The more intense program activity in the developing world also explains why the IMF came to be seen as an institution that uses funds from higher-income countries to grant crisis loans to lowerincome countries. Indeed, up until the global financial crisis of 2008-2009, much of the academic and popular debate of the IMF's role in coping with crises was relegated to a discussion of episodes in emerging markets, culminating with Argentina’s spectacular default in December 2001. Largely forgotten is the fact that in the decades immediately after its creation at the end of World War II, many IMF programs were providing balance-of-payments support to the comparatively wealthy economies of Europe. Figure 4 documents the incidence of IMF programs over 1950-2014 in advanced and emerging market-developing country groups separately, making plain the swings in the pendulum from advanced

\footnotetext{
${ }^{4}$ For a list of when countries joined the IMF by date, see https://www.imf.org/external/np/sec/memdir/memdate.htm and the data underlying Figure 2.
} 
economies in the 1950s and 1960s to emerging markets in the mid-1980s and back to advanced economies after a 30-year hiatus in 2008.

Figure 2. International Monetary Fund: 1945-2015 Number of Member Countries

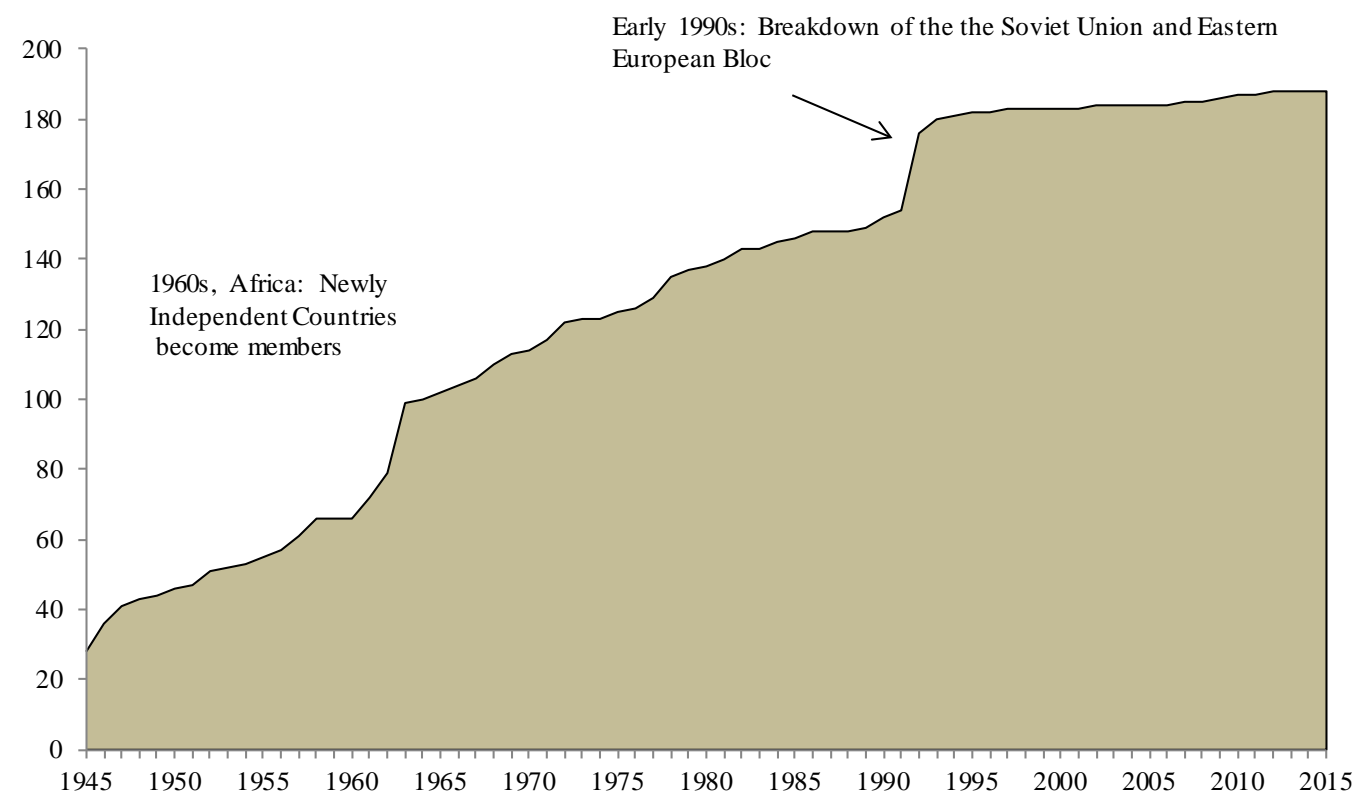

Sources: International Monetary Fund, Financial Position in the Fund, all member countries.

Figure 3. The Incidence of IMF Programs, 1945-2015

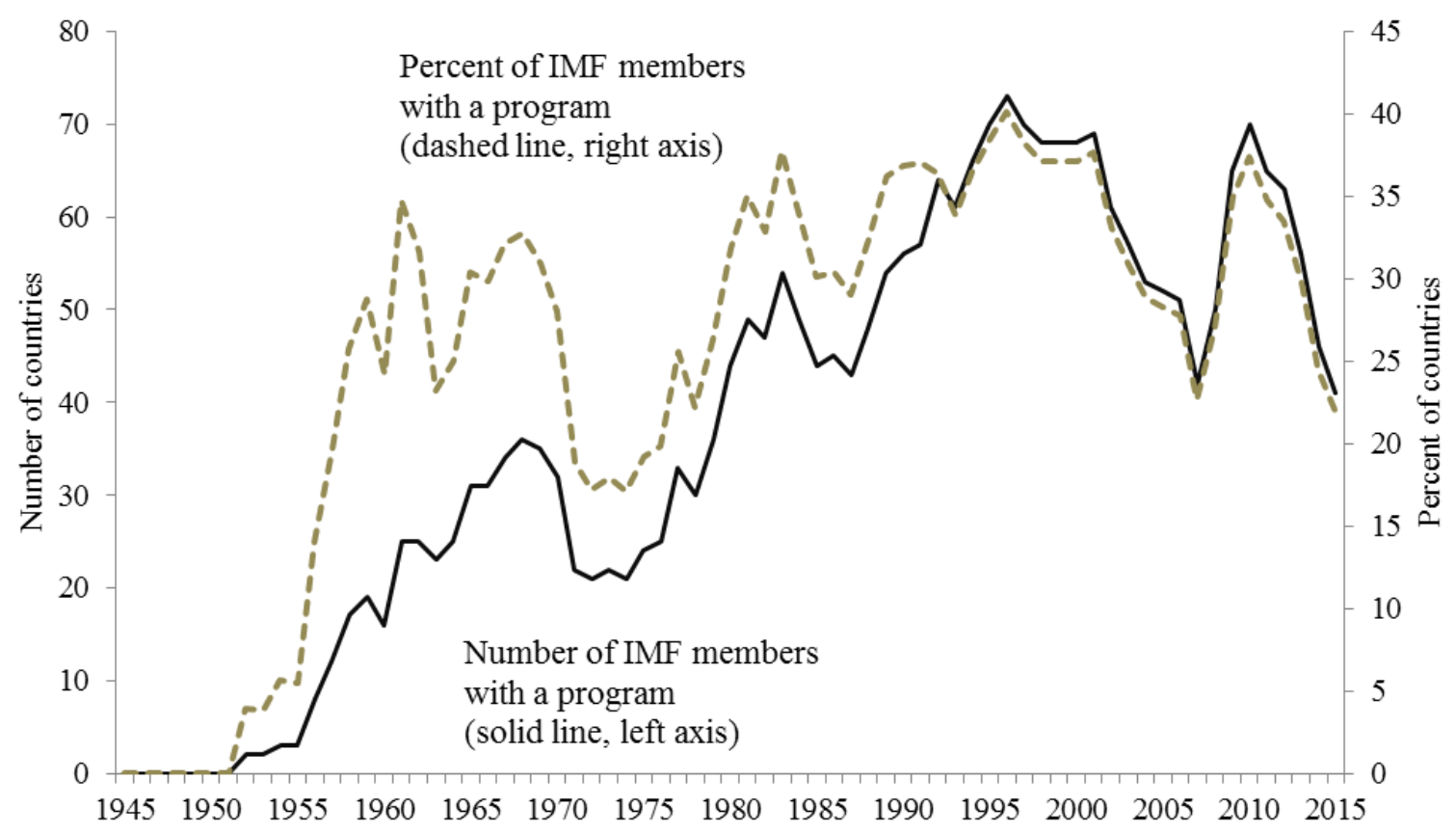

Sources: Gold (1970), International Monetary Fund, Monitoring of Fund Arrangements (MONA) Database, Joyce (2005), Killick (1995), Mody and Saravia (2006). 
Figure 4. From Advanced Economies to EMEs and Back: Program Incidence, 1950-2014

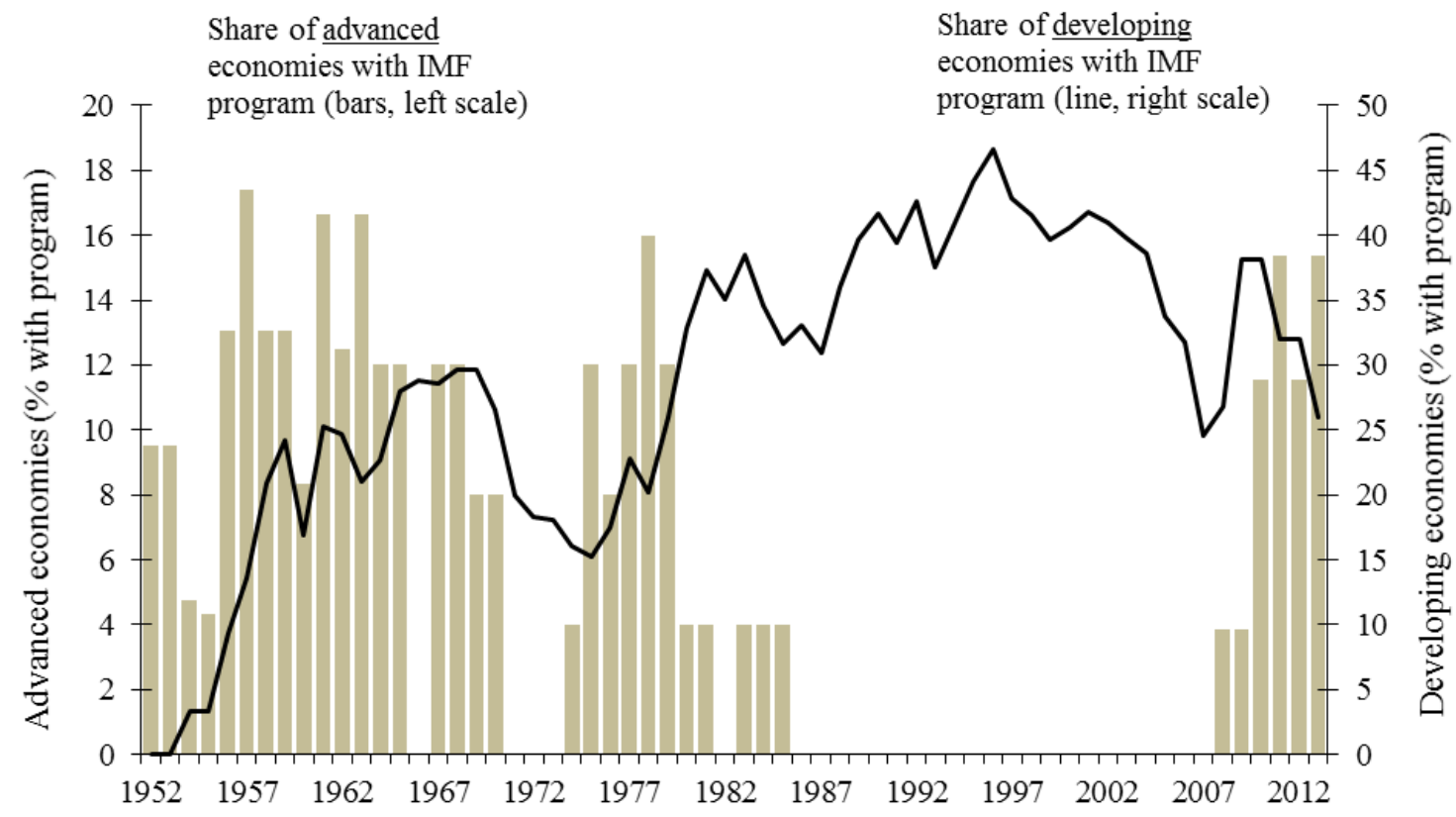

Sources: Gold (1970), International Monetary Fund, Monitoring of Fund Arrangements (MONA) Database, Joyce (2005), Killick (1995), Mody and Saravia (2006).

\section{II.1 Early Decades: Significant Lending to Advanced Economies}

There were no IMF lending programs in the first seven years after its creation in 1945. Rather, the Marshall Plan of 1948-1951 accounted for the dominant form of international transfers (via both loans and grants) to 18 European countries (if the Free Territory of Trieste is counted) along with eight Asian countries, as well as Israel and a few other countries in the Middle East. While the Marshall plan is usually discussed in terms of humanitarian aid and reconstruction finance, its loans and grants also provided much-needed balance of payments support, as the economies in question faced the twin challenges of having significant needs for imported consumer and industrial goods and limited reserves of hard currency to make such purchases. This problem was known at the time as the "dollar gap" (for discussion, see Behrman 2007, especially Chapter 8). Some countries, most notably the United Kingdom, had also inherited a high level of war-time debt to service. In others, including France, Germany, Italy and Japan, roaring inflation at the end of the war and the beginning of the peace had wiped out significant portions of the domestic stock of debt (Reinhart and Sbrancia 2015). 
In 1952, Belgium and Finland were the first countries to use IMF resources. Between 1956 and 1977, the United Kingdom alone had 11 IMF programs. In the early years of the IMF, the classic lending instrument was a Stand-By Arrangement, in which funds are provided on the condition that the borrower addresses its underlying imbalances, and were typically granted as one-year programs that in a few cases were renewed. By 1977, at the outset of the last of the UK programs, the duration of that Stand-By arrangement was stretched to two years. This trend has persisted. For example, Turkey's most recent Stand-by program in 1999 was a three-year arrangement, reflecting a re-interpretation of what constitutes temporary support (an issue we take up in the next section). ${ }^{5}$

In these early decades of the IMF, France, Iceland, Italy, Portugal, Spain, and the United States, among others, all borrowed from the International Monetary Fund. The fact that Greece did not have an IMF program during this era largely stems from the fact that the country was in default from 1932 through 1964 and had rather minimal interaction with world capital markets. It was also the case that Greece was a major recipient of aid, rather than loans, during the encompassing umbrella of the Marshall Plan.

The composition of the early developing-country clients of Fund also differed from what was to emerge in the decades that followed. In the pre-OPEC era (OPEC was founded in 1961), Iran and Syria had a very brief stint with Fund programs. It has not been repeated since. South Africa was the only African country in the IMF until the late 1950s, when Ghana and Morocco joined the membership. However, some of the countries that were to become chronically attached to the IMF (as we discuss in the next section) — Argentina, El Salvador, Pakistan, the Philippines, among others — had already made their appearance at the IMF lending window by the late 1950s or early 1960s.

\section{II.2 Emerging Market, Transition Economies and Turmoil}

Many emerging market economies experienced an economic boom in the 1970s. For some of these countries, the driving force was the sharp rises in oil prices in the mid- and late 1970s (DiazAlejandro 1983, 1984). The surge in oil prices, accompanied by inflation world-wide, lifted commodity

\footnotetext{
${ }^{5}$ The current structure for Stand-By Arrangements, updated most recently in 2009, is explained at https://www.imf.org/external/np/exr/facts/sba.htm.
} 
prices in general. A belief that these higher commodity prices would last into the long-term meant that lending to commodity producers came to be seen as a lucrative activity. A common dynamic of international finance at this time was the so-called "recycling of the petrodollars," which refers to the recurring pattern whereby oil-producing countries deposited their surging dollar-denominated export revenues in international financial intermediaries that, in turn, aggressively expanded their lending to a broad range of developing countries.

The spectacular boom was followed by a protracted bust, as has been a common historical pattern (Kindelberger 1978; Kaminsky and Reinhart 1999; Reinhart and Rogoff 2009; Gourinchas and Obstfeld 2012). The spike in US interest rates in October 1979 abruptly brought the feast-phase of the cycle to an end. Given that a significant share of the new debts of emerging-market economies were either short-term or carried a variable interest rate, there was a swift and adverse effect on their national balance sheets. Furthermore, the sharp appreciation of the US dollar accompanying the Federal Reserve's tight monetary policy further undermined the solvency of those nations that had taken on dollar-denominated debt (whether those debts were public or private). By the early 1980s, commodity and oil prices plunged, and debt-servicing costs for the developing world skyrocketed. The decade of the 1980s is often referred to as the "lost decade" for Latin America. While emerging markets in Asia fared better in terms of growth, inflation, and gains in social indicators, commodity-intensive Africa fared just as badly in general and in several dimensions worse. For emerging markets as a whole, the 1980s was the most dismal decade since the 1930s.

The number of IMF lending programs more than doubled from 1976 to 1983 . The new wave of IMF clients was comprised mostly of what were called "less developed countries" or LDCs in the language of the day. This marked shift in the composition of what kind of countries were borrowing from the IMF influenced the modalities and scope of the programs. In 1987, the IMF introduced the Enhanced Structural Adjustment Facility (ESAF) program, which focused on making low-interest loans to low-income countries. The debt crisis of the 1980s was eventually addressed after several years. One main step was the external debt restructurings in 16 countries (mostly in Latin America) under the Brady Plan of 1989, in which creditors agreed to write down the debts they were owed in exchange for 
being issued new debt that was more likely to be repaid. The IMF participated by setting aside some of its own loans. In addition, high-inflation countries in Latin America and elsewhere undertook macroeconomic stabilization and anti-inflation programs,

In the 1990s, the breakdown of the Soviet Union and its satellite community ushered new clients to the IMF. A rough categorization of the new members would place much of Eastern Europe in the middle-to-high income category and the former Soviet republics in the lower-income strata. Among this lower-income group in particular, a number of these countries have become recurring and chronic users of Fund resources since joining the Fund in the 1991-1993 period. As the next section documents, this further lengthened the "effective” duration of IMF programs.

\section{II.3 Post-2008: Crisis in the Eurozone}

In the years before the global financial crisis erupted in 2008, many countries in the periphery Europe, as well as Iceland, the United Kingdom, and the United States experienced a boom in capital inflows. As in so many pre-crisis booms, borrowing from the rest of the world supported a combination of larger current account deficits, domestic lending surges, and asset price booms. For example, in 2008, the current account deficits in Iceland, Greece, Portugal, and Ireland had reached records of 28, 15, 13, and percent of GDP, respectively. As the global financial crisis severely sapped economic activity and confidence in sovereign government finances eroded, the access to international capital markets that had been taken for granted by advanced economies during most of the post-World War II era came to a sudden stop. Iceland was the first to start an IMF program in 2008, followed by Greece and Ireland in 2010 and Portugal in 2011.

This episode brought an enormous rise in the sheer volume of lending (in real terms) directed at the higher-income economies (Figure 5): from 2008 to the present, the IMF has loaned more than \$200 billion, of which about two-thirds went to advanced economies like Greece, Iceland, Ireland and Portugal. This emphasis on lending to advanced countries represented the reemergence of an earlier pattern. In the 1950s and 1960s, advanced economies accounted for a larger share of total approved lending than emerging and developing economies. Table 1 shows the largest IMF programs during its history, as measured by the dollar amounts of the loans approved (in real 2009 dollars) and in relation to 
the country's quota and GDP. The Mexican and Indonesian programs of 1995 and 1997 made headlines at the time with loans of 6-7 times their quota, but they are dwarfed by the more recent wave of IMF lending. The sheer scale of IMF lending during the most recent crisis, whether the country is in the advanced or emerging category (like Hungary, Romania, and Ukraine), is a multiple of what were considered record-sized programs in the 1990s and early 2000s.

Figure 5. From Advanced Economies to EMEs and Back: Lending Volume, 1950-2014

IMF Lending Amounts Approved, by Decade (in billion 2009 US\$, excluding flexible credit lines)

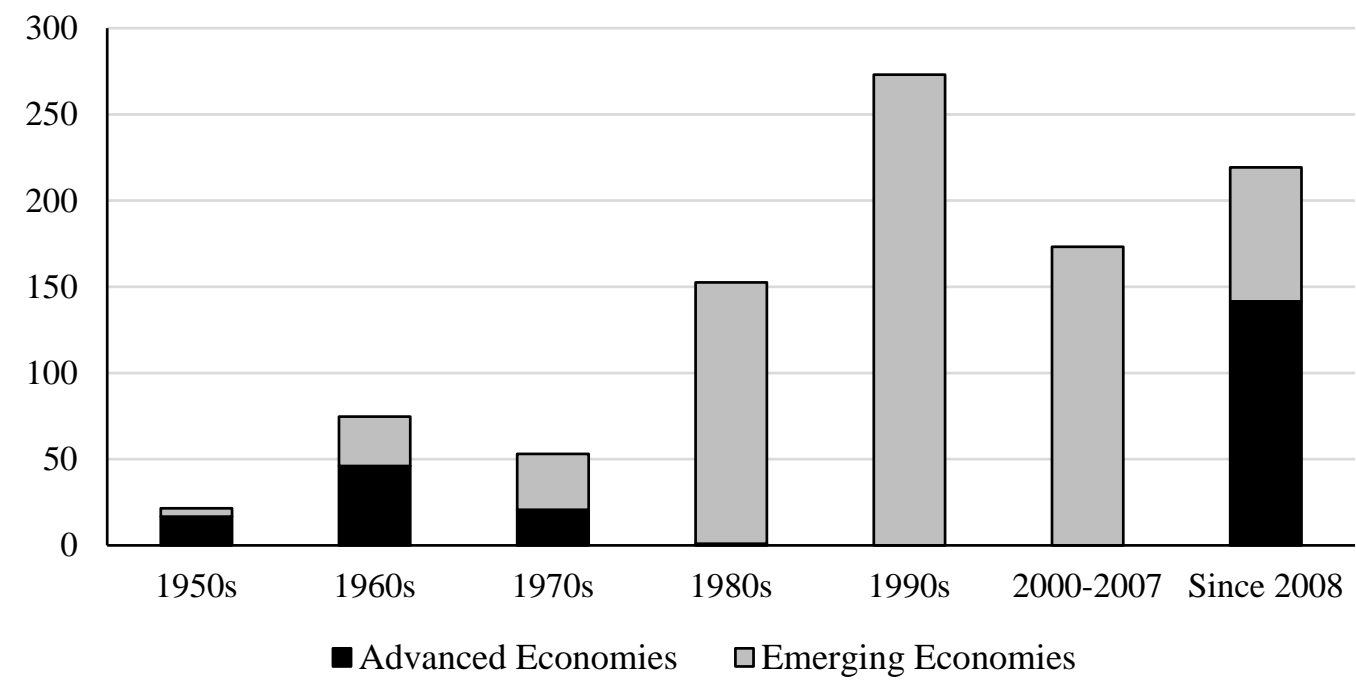

Sources: Gold (1970), International Monetary Fund, Monitoring of Fund Arrangements (MONA) Database, Joyce (2005), Killick (1995), Mody and Saravia (2006)

If one scales IMF lending by the recipient country’s GDP, the median program was less than 2 percent of GDP through the late 1970s (Figure 6) — which is consistent with what might be expected in connection with temporary balance-of-payments support. For several years during the various debt crises of the 1980s, the median IMF program reached about 4 percent of GDP and remained in that range through the worldwide lull in financial crises during 2003-2007. The sheer size of the post-2008 IMF programs has no historical antecedent, as programs accounted for 10-16 percent of GDP of the recipients. In addition, these post-2008 programs offered the same three-year duration of loans that the Extended Credit Facility offered to low income countries. 
Table 1. The Largest IMF Programs

\begin{tabular}{llll}
\hline \hline Country, program year & $\begin{array}{l}\text { In million } \\
\text { 2009 US\$ }\end{array}$ & $\begin{array}{l}\text { Percent of } \\
\text { Quota }\end{array}$ & $\begin{array}{l}\text { Percent of } \\
\text { GDP }\end{array}$ \\
\hline Greece 2010 & 39,851 & 3212 & 13.71 \\
Ireland 2010 & 29,347 & 2322 & 14.19 \\
Portugal 2011 & 36,326 & 2306 & 15.76 \\
Greece 2012 & 34,700 & 2159 & 14.67 \\
Korea 1997 & 27,309 & 1938 & 3.81 \\
Turkey 1999 & 25,674 & 1560 & 8.23 \\
Turkey 2002 & 19,519 & 1330 & 7.14 \\
Romania 2009 & 17,645 & 1111 & 10.74 \\
Hungary 2008 & 16,783 & 1015 & 10.80 \\
Brazil 2002 & 41,677 & 902 & 7.03 \\
Ukraine 2008 & 17,518 & 802 & 9.66 \\
Argentina 2000 & 27,280 & 800 & 6.49 \\
Ukraine 2010 & 15,076 & 729 & 11.19 \\
Pakistan 2008 & 11,524 & 700 & 6.72 \\
Turkey 2005 & 10,697 & 691 & 2.03 \\
Mexico 1995 & 24,284 & 688 & 5.33 \\
Indonesia 1997 & 14,690 & 557 & 5.32 \\
Brazil 1998 & 17,912 & 480 & 1.68 \\
Argentina 2003 & 14,504 & 424 & 8.01 \\
Brazil 2001 & 18,454 & 400 & 2.79 \\
Russian Fed. 1996 & 24,976 & 306 & 4.90 \\
India 1981 & 12,115 & 291 & 2.99 \\
United Kingdom 1977 & 11,146 & 120 & 1.53 \\
\hline \hline
\end{tabular}

Sources: Gold (1970), International Monetary Fund, Monitoring of Fund Arrangements (MONA) Database, Joyce (2005), Killick (1995), Mody and Saravia (2006). 
Figure 6. IMF Programs Get Bigger, 1960-2014

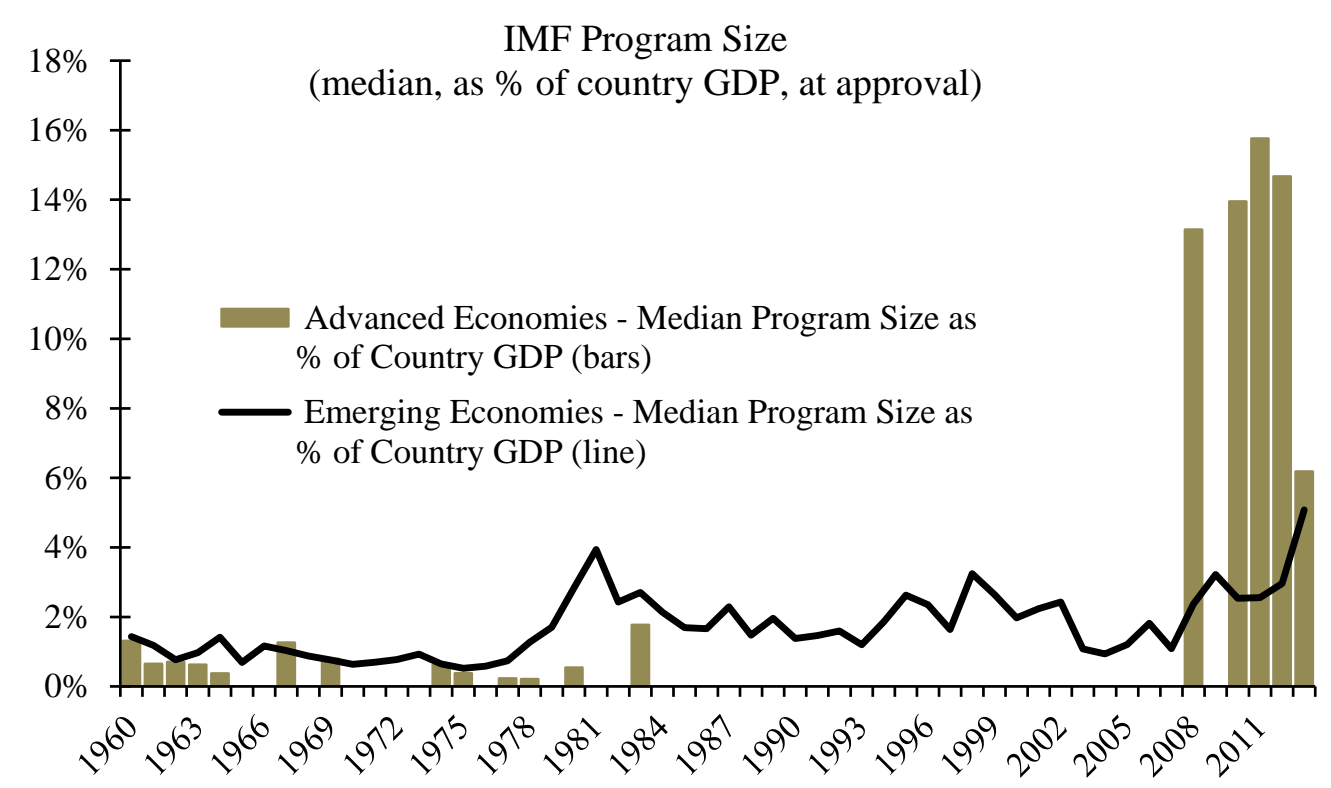

Sources: Gold (1970), International Monetary Fund, Monitoring of Fund Arrangements (MONA) Database, Joyce (2005), Killick (1995), Mody and Saravia (2006).

\section{Evolving Demands}

As the composition of the IMF's clientele evolved during the past 70 years since the institution’s birth, so did common challenges or “types” of crises facing the IMF and its membership.

\section{III.1 From Currency Crises to Banking and Sovereign Debt Crises}

Indeed, currency crises (or realignments) were not uncommon during the Bretton Woods era, as highlighted by the light bars in Figure 7 plotting the number of currency crises per year over 1950-2014. The year-by-year count of banking crises is given by the dark bars. As the figure makes plain, while realignments (often in the form of large devaluations followed by re-pegging) were commonplace, banking crises during the era of capital controls and tightly regulated financial markets were rare. ${ }^{6}$ Owing to a combination of a broader adoption of more flexible exchange rate arrangements and a decade of prosperity in emerging markets, the incidence of currency crashes diminished through 2012.

\footnotetext{
${ }^{6}$ Largely owing to a combination of a broader adoption of more flexible exchange rate arrangements and a decade of prosperity in emerging markets during 2003-2013 the incidence of currency crashes in recent years diminished in comparison to the 1950s-1970s (let alone the turbulent 1980s).
} 
As emerging market exchange rate volatility has climbed noticeably (once again) it remains to be seen whether currency woes resurface.

Figure 7. Number of Banking and Currency Crises per Year, 1950-2014

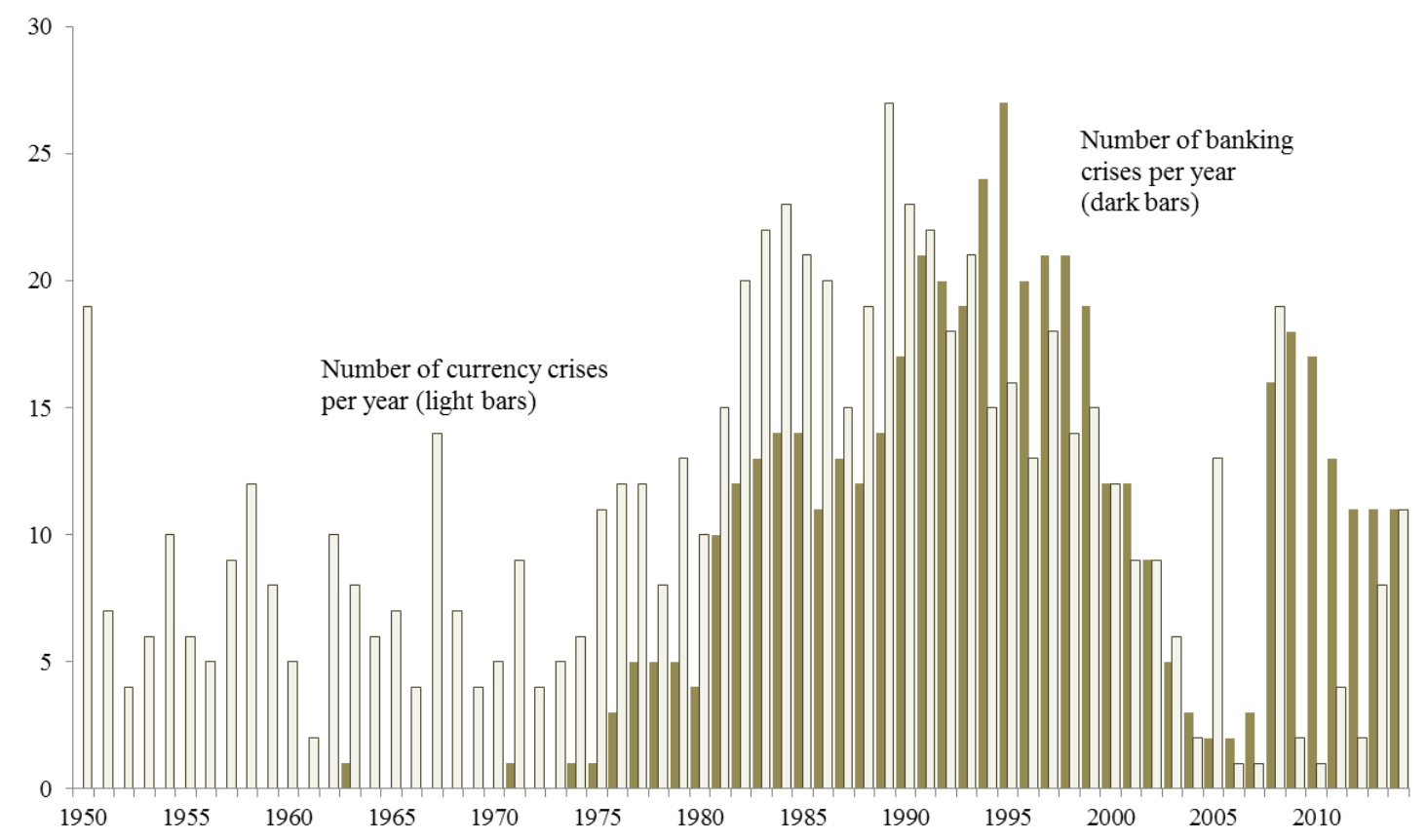

Sources: Reinhart and Rogoff (2009) and sources cited therein; updates by Reinhart at http://www.carmenreinhart.com.

Most currency realignments are essentially temporary disturbances. Cooper (1971) and Krueger (1978), for example, reach this conclusion after reviewing large currency devaluation episodes during 1951-1970 (many of which were a part of the conditionality associated with an IMF adjustment program). Kaminsky and Reinhart (1999) compare the effects of currency crises, banking crises, and "twin” crises involving both in a more up-to-date sample. In all of these studies, currency devaluations were associated with either a decline in output or a slowdown in growth but the effects were comparatively small and short-lived. In contrast, it is a well-documented regularity that recessions associated with systemic banking crises tend to be severe and protracted, as the global experience since 2008 has illustrated anew (for broad coverage of this issue see, Kaminsky and Reinhart 1999;

Dell'Ariccia et al.2008; Reinhart and Rogoff 2009; Claessens et al. 2009; Reinhart and Reinhart 2010; Gourinchas and Obstfeld 2012 and Jorda et al. 2012). Cases of sovereign insolvency often involve even more protracted slumps; indeed, sovereign default spells lasting a decade are not uncommon (Reinhart 
and Rogoff 2009; Cruces and Trebesch 2013).

Taken together, these observations about the relative incidence of currency versus banking crises and their comparative speeds of recovery has implications for the kind of support that may have been deemed appropriate by the IMF.

\section{III.2 Growing Duration of IMF Lending Programs}

As shown in Figure 8, during the 1950s and 1960, according to our calculations, the duration of IMF lending programs oscillated in a one-to-two year range (the Stand-By Arrangements during the 1950s and 1960s were one-year programs—but a succession of one-year programs was possible). By the end of the 1990s, average duration of an IMF interaction had climbed to three years. The presence of frequent systemic banking crises as well as the increasing incidence of protracted sovereign defaults may partially account for a lengthening in the duration of IMF programs in 1980-1990s and for an increase in their size relative to GDP.

Figure 8. Alternative Measures of Program Persistence, 1950-2015

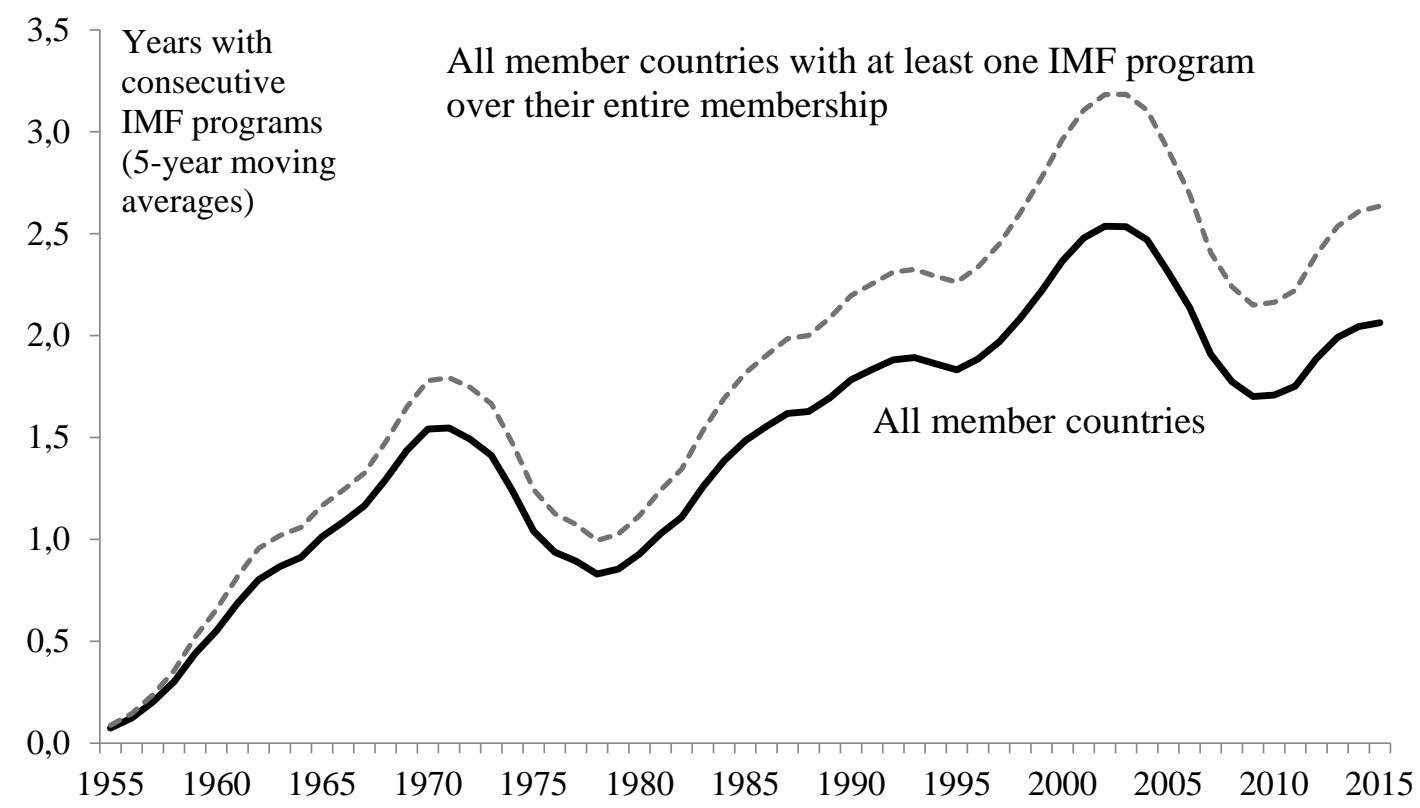

Sources: Gold (1970), International Monetary Fund, Monitoring of Fund Arrangements (MONA) Database, Joyce (2005), Killick (1995), Mody and Saravia (2006). 
Table 2. Share of years with an IMF Program since joining the Fund

\section{Frequency Distribution}

\begin{tabular}{lrr}
\hline \hline & $\begin{array}{r}\text { Number } \\
\text { of countries }\end{array}$ & $\begin{array}{r}\text { Share of } \\
\text { countries }\end{array}$ \\
\hline No IMF programs & 42 & 22.3 \\
Share of years is between 0 and 10 & 23 & 12.2 \\
Share of years is between 10 and 20 & 18 & 9.6 \\
Share of years is between 20 and 30 & 16 & 8.5 \\
Share of years is between 30 and 40 & 19 & 10.1 \\
Share of years is between 40 and 50 & 22 & 11.7 \\
Greater than or equal to 50 & 48 & 25.5 \\
Total & 188 & 100 \\
\hline \hline
\end{tabular}

Sources: Gold (1970), International Monetary Fund, Monitoring of Fund Arrangements (MONA) Database, Joyce (2005), Killick (1995), Mody and Saravia (2006), and authors’calculations.

We also find an increasing number of repeated IMF programs, resulting in "serial lending”. Table 2 presents the frequency distribution for the share of years that a country had an IMF program during the time that the country belonged to the IMF. Of the current 188 member countries, more than a quarter of these (25.5 percent) have had an IMF program 50 percent of the time (or more) that they were an IMF member; 37 percent of the countries have been on IMF programs 40 percent of the time or more. Forty-two countries (22 percent) never had a Fund program, with oil-exporting countries and small states accounting for a significant share of this latter group.

Table 3 lists countries with the heaviest recurring use of IMF resources, showing both the share of years with IMF programs (breaking out the data summarized for all member countries in Table 2) and the longest spell (in years) of consecutive programs. Topping the list, Uganda and Malawi (both member countries since the mid-1960s) have had consecutive IMF programs for nearly 30 years. The Joyce (2005) study (see also Figure 8) suggested income levels were an important factor in explaining the duration of programs. With lower income countries having limited or no access to private capital markets during long stretches of time, one potential story is that the IMF (along with other sources of official financing) has emerged as a near-permanent substitute for access to private capital markets for many low-income countries. It is unlikely, however, that this is the whole story, because the list of countries with serial IMF programs shown in Table 3 includes a substantial number of middle-income 
countries with an incidence of IMF programs during the time that they have been members in excess of 30 percent.

Figure 9. Country Income (p.c., PPP adjusted) and the Incidence of IMF Programs, 1945-2015

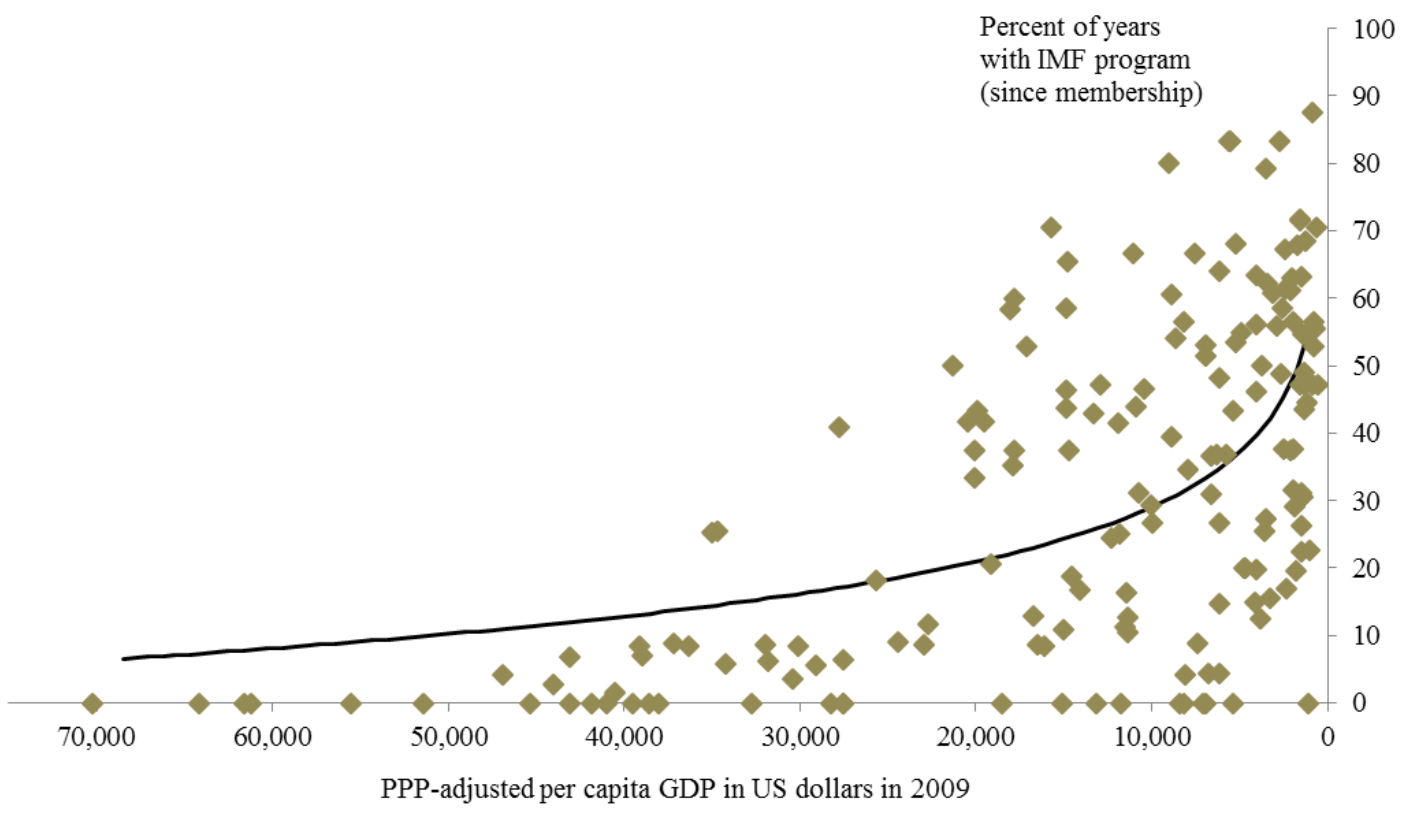

Sources: Gold (1970), International Monetary Fund, Monitoring of Fund Arrangements (MONA) Database and World Economic Outlook, Joyce (2005), Killick (1995), Mody and Saravia (2006), and authors'calculations. 
Table 3. Years with IMF programs: Incidence and Durations of Spells Countries with heaviest recurring use

\begin{tabular}{|c|c|c|c|}
\hline Country & $\begin{array}{l}\text { Share of years } \\
\text { with programs }\end{array}$ & $\begin{array}{l}\text { Longest } \\
\text { spell (years) }\end{array}$ & $\begin{array}{l}\text { Membership } \\
\text { year }\end{array}$ \\
\hline Uganda & 67.9 & 29 & 1963 \\
\hline Malawi & 70.6 & 28 & 1965 \\
\hline Burkina Faso & 47.2 & 25 & 1963 \\
\hline Argentina & 60.0 & 24 & 1956 \\
\hline Mali & 71.7 & 21 & 1963 \\
\hline Haiti & 71.4 & 21 & 1953 \\
\hline Mauritania & 62.3 & 20 & 1963 \\
\hline Tanzania & 63.0 & 20 & 1962 \\
\hline Togo & 44.4 & 20 & 1962 \\
\hline Philippines & 53.5 & 20 & 1945 \\
\hline Jamaica & 56.6 & 20 & 1963 \\
\hline Panama & 47.1 & 20 & 1946 \\
\hline Guinea & 54.7 & 19 & 1963 \\
\hline Colombia & 46.5 & 18 & 1945 \\
\hline Costa Rica & 41.4 & 18 & 1946 \\
\hline Peru & 60.6 & 18 & 1945 \\
\hline Gabon & 52.8 & 17 & 1963 \\
\hline Zambia & 60.8 & 17 & 1965 \\
\hline Bulgaria & 65.4 & 17 & 1990 \\
\hline Guyana & 68.0 & 17 & 1966 \\
\hline Mozambique & 87.5 & 16 & 1984 \\
\hline Romania & 70.5 & 16 & 1972 \\
\hline Bolivia & 54.9 & 16 & 1945 \\
\hline El Salvador & 51.4 & 16 & 1946 \\
\hline Jordan & 31.3 & 16 & 1952 \\
\hline Benin & 47.2 & 15 & 1963 \\
\hline Congo, Dem. Rep. (Kins] & 47.2 & 15 & 1963 \\
\hline Liberia & 55.6 & 15 & 1962 \\
\hline Sierra Leone & 68.5 & 15 & 1962 \\
\hline Nicaragua & 50.0 & 15 & 1946 \\
\hline Armenia & 83.3 & 15 & 1992 \\
\hline Georgia & 83.3 & 15 & 1992 \\
\hline Madagascar & 54.7 & 14 & 1963 \\
\hline Morocco & 48.3 & 14 & 1958 \\
\hline Senegal & 61.1 & 14 & 1962 \\
\hline Mongolia & 64.0 & 14 & 1991 \\
\hline Algeria & 24.5 & 13 & 1963 \\
\hline Korea & 41.0 & 13 & 1955 \\
\hline Paraguay & 26.8 & 13 & 1945 \\
\hline Uruguay & 58.6 & 13 & 1946 \\
\hline Burundi & 52.8 & 12 & 1963 \\
\hline Cote d'Ivoire & 58.5 & 12 & 1963 \\
\hline Ghana & 55.9 & 12 & 1957 \\
\hline Kenya & 67.3 & 12 & 1964 \\
\hline Albania & 80.0 & 12 & 1991 \\
\hline Honduras & 63.4 & 12 & 1945 \\
\hline
\end{tabular}

Notes: The share of years with programs is calculated from the year the country becomes a member (shown in the last column) through 2015. 


\section{III.3 Chronic Debt Burdens and Lending Into Insolvency}

The heavy use of IMF lending by so many countries is clearly not a result of short-term currency crises, and the historical incidence of banking crises does not seem sufficient to explain it, either (Reinhart and Rogoff 2009, Ch. 10). More plausible is that IMF lending programs increasingly occur in countries facing problems with insolvency of sovereign and sometimes private debt.

A starting point in examining the nexus between IMF program lending and debt defaults is to determine the extent of overlap between the two, starting with sovereign defaults and restructurings on private creditors. ${ }^{7}$ These highly visible credit events involve bank loans, bonds, or both. In numerous episodes, there were also significant defaults on trade credit (see also the analysis by Erce 2013). However, as we note in Reinhart and Trebesch (2015), a fuller picture of solvency also requires an assessment of a debtor country's standing with its official creditors. For example, the most prominent debt crisis of the last few years, in Greece, now revolves almost entirely around the country's debts to official creditors including the IMF. While official creditors are not the main story for most middle-tohigh income countries, they play a dominant role in many low-income countries. It is important, therefore to also assess to what extent official debt is in default, under restructuring, or in substantial arrears. This task was recently attempted by Beers and Nadeau (2015), mainly based on World Bank and Paris Club data on defaults and arrears with official creditors. We use their data to complement our earlier history of private and sovereign credit events, which allows us to study the overlap between the augmented (private plus official) defaults and IMF programs on a country-by-country basis.

The pattern we observe is that the share of IMF programs with countries that are either in default or in the process of restructuring with private creditors climbs from less than 20 percent of all programs during $1950-1970$ s to more than 70 percent in the late 1980 s. $^{8}$ The first country to have an IMF program overlap with a default was Argentina in 1958 during the post-Peron budget crisis. The more famous defaults began in earnest in the summer of 1982, as Mexico defaulted in August of that year. However, smaller countries like Bolivia and much of Central America and numerous African

\footnotetext{
${ }^{7}$ For a chronology of sovereign defaults and restructurings on external debt by private creditors see Reinhart and Rogoff (2009) and Cruces and Trebesch (2013), both updated in Reinhart and Trebesch (2015), and S\&P (2015). ${ }^{8}$ In 1989, the IMF modified its policy of non-toleration of external arrears by creating the "Lending into Arrears Policy”, which allowed countries under a program to have arrears towards private creditors as long as they show a "good faith" to negotiate a potential debt restructuring and settle the arrears (see Diaz-Cassou et al. 2008).
} 
countries were already in default as early as 1980. During the 1990s, however, the share of IMF programs involving private debt default then started to fall. Part of the reason was the Brady plan in the early 1990s, which diminished the number of debtors in default. Another important step in reducing debt burdens involved the Heavily Indebted Poor Countries (HIPC) Initiative started by the IMF and the World Bank in 1996, which eventually allowed 39 low-income countries to have existing debts reduced in exchange for reforms that made paying the remainder of the debt more likely. ${ }^{9}$

Many emerging markets also experienced widespread public and private deleveraging following the Asian crisis of 1997-1998, which made debt defaults in these countries less likely. Finally, the increase in IMF program size, coupled with large-scale bailouts by other official lenders (e.g. by the U.S. Treasury or the Eurozone institutions EFSF and ESM) have made sovereign default less likely, as private creditor are repaid with new official loans. By 2013, fewer than 10 percent of all IMF lending programs involved a default by private creditors, as shown in Figure 10.

Figure 10. Share of IMF Programs that Overlap with a Default or Restructuring Spell: 1952-2013

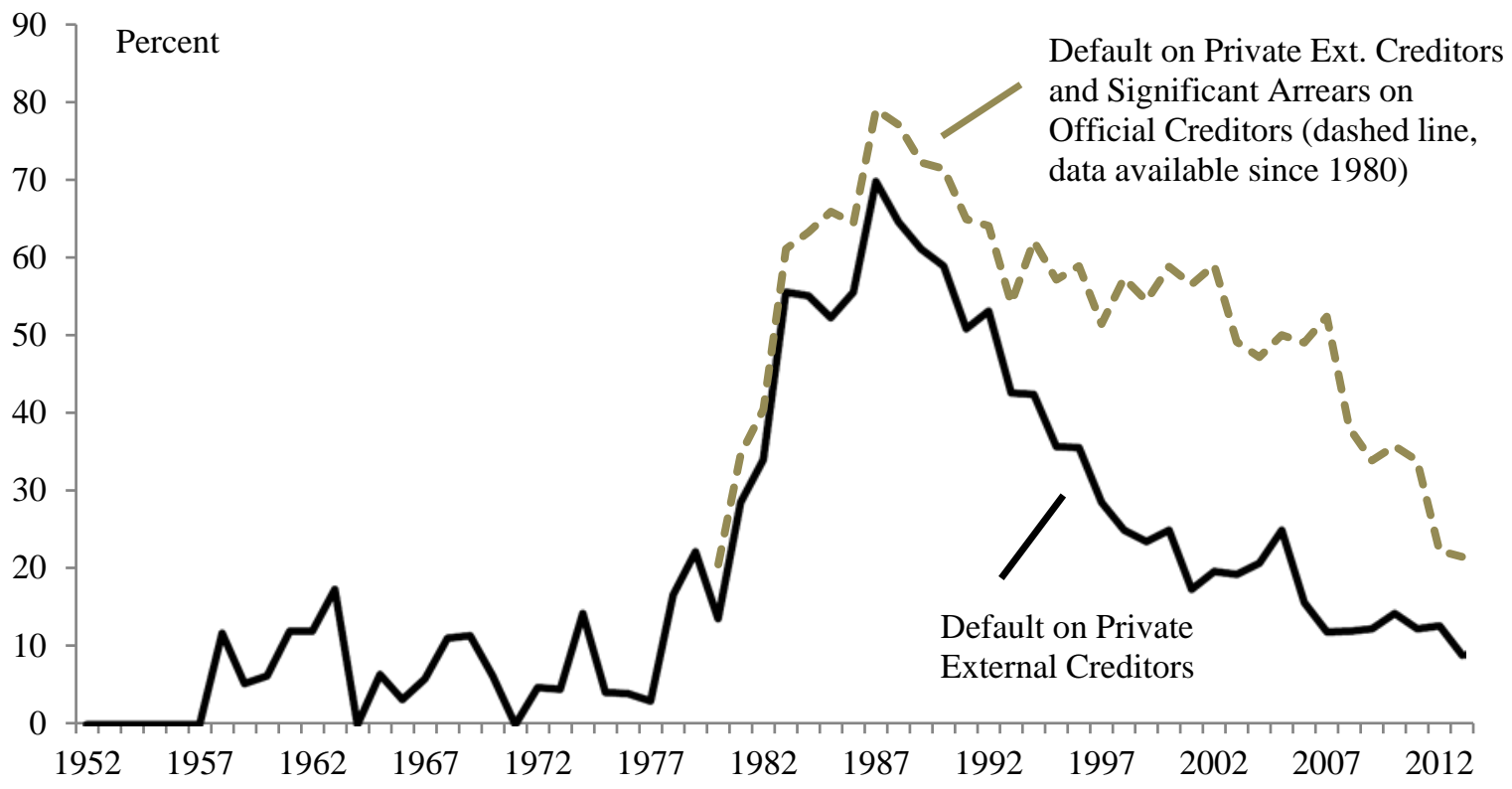

Note: Data on sovereign defaults to private external creditors is from Reinhart and Rogoff (2009), Cruces and Trebesch (2013), and Reinhart and Trebesch (2015). The dotted line adds to this instances of default on official creditors and their overlap with IMF programs, with data available since 1980. A country is coded as having "significant and persistent arrears" to official creditors if these arrears (including to the IMF and World Bank) exceed 1\% of GDP for three consecutive years or more, using data on official arrears from the World Bank (2015) and Beers and Nadeau (2015). Data on GDP in current US\$ is from the IMF WEO database.

\footnotetext{
${ }^{9}$ https://www.imf.org/external/np/exr/facts/hipc.htm
} 
Figure 10 also shows that the private-only measure of default shows just part of the picture and significantly understates the weak and chronic state of fiscal finances, in particular in low-income countries (and since 2010 in several European countries). Credit events involving official creditors do not often make headlines, with the notable exception of Greece in 2015 (even the restructuring of significant levels of official debt in Ireland, Greece and Portugal in 2013 received little attention). Despite the limited coverage, arrears on official debts are both large and frequent, as show in Schlegl et al. (2015). Accordingly, the dotted line in Figure 10 shows that defaults on official debt (defined as significant and persistent arrears) ${ }^{10}$ are a frequent by-product of IMF lending programs until this day.

More specifically, in the 1990s and 2000s, about 40 percent of all IMF lending programs involve some sort of default, restructuring or arrears on official debt. This is a remarkable and not widely known fact, and is surprising given that the Fund's policies dictate (at least in principle) that the Fund should not lend in the presence of arrears to official creditors. ${ }^{11}$ Under exceptional circumstances this rule of non-toleration of arrears can be waived, for example when countries are in the process of negotiating over debt relief with official creditors. However, the data suggests that arrears to official creditors are the norm rather than the exception in many poor countries borrowing from the IMF.

The intersection between lending programs and sovereign defaults or arrears provides insight as to why so many countries have a track record that is filled with year upon year of consecutive IMF lending programs. Indeed, one of the reasons why some countries have become chronic borrowers from the IMF is that it is effectively a way of ever-greening their ongoing loans to both private and official creditors. ${ }^{12}$ Another reason is that countries asking for debt relief from the Paris Club or under the HIPC initiative are often asked to agree to an IMF adjustment program first (Rose 2005 finds that $80 \%$ of Paris Club deals coincide with an IMF program signed in the same year). Yet, we do not suggest that debt problems are a complete explanation for the serial lending patterns we observe. Stone (2004)

\footnotetext{
${ }^{10}$ A country is coded as having "significant and persistent arrears" to official creditors if these arrears (including to the IMF and World Bank) exceed 1\% of GDP for three consecutive years or more.

${ }^{11}$ Most recently, in the context of the Ukraine debt restructuring, an IMF spokesman confirmed that "The Fund does maintain a policy of non-toleration of arrears to official bilateral creditors." See Transcript of a Press Briefing by William Murray, Deputy Spokesperson https://www.imf.org/external/np/tr/2015/tr032615.htm.

${ }^{12}$ Details behind these results appear in Figure A.6 in the Appendix. As with all other time series, the Data Appendix V provides the relevant sources.
} 
provides compelling evidence for 53 African countries from 1990 to 2000 that shows that the typical IMF's loans-for-reform contract lacks credibility, because donor countries intervene to prevent rigorous enforcement; specifically countries with influential developed-country patrons are subject to less rigorous enforcement (as measured in terms of shorter program suspensions). Bird et al. (2004), who focus on IMF lending programs over 1980-1996, find that recidivist borrowers have lower reserve holdings, larger current account deficits and capital outflows, lower but less volatile terms of trade, larger debt service and external debt ratios, lower investment rates and per-capita income, and weak governance. Barro and Lee (2005) conclude that both economic factors and measures of political and economic connections to the United States and, to a lesser degree, to the major European countries play significant roles in raising the probability and size of IMF lending. Collectively, these studies suggest that both economic fundamentals as well as political influence help explain why so many countries are "addicted to the IMF."

Figure 11 plots average public debt/GDP across all countries with an IMF program that year and reinforces some of the conclusions that emerged from examining the coincidence of programs and external default. The solid line represents the average across programs in advanced economies. As there is an approximate 30-year gap in which there were no programs, the solid line only re-appears after 2008. In the 1950s, the average is heavily influenced upward by the United Kingdom, where public debt remained above $100 \%$ of nominal GDP for most of the decade. The recent levels for the advanced economies, surpass by a considerable margin their earlier history. For the developing countries (HIPC and middle income), the trend from the 1960s to the 1980s is unmistakably upwards and consistent with the higher observed incidence of default during that period shown in Figure 10. 
Figure 11. Public Debt/GDP (in percent) for All Ongoing IMF Programs (average across all countries with a program in that year)

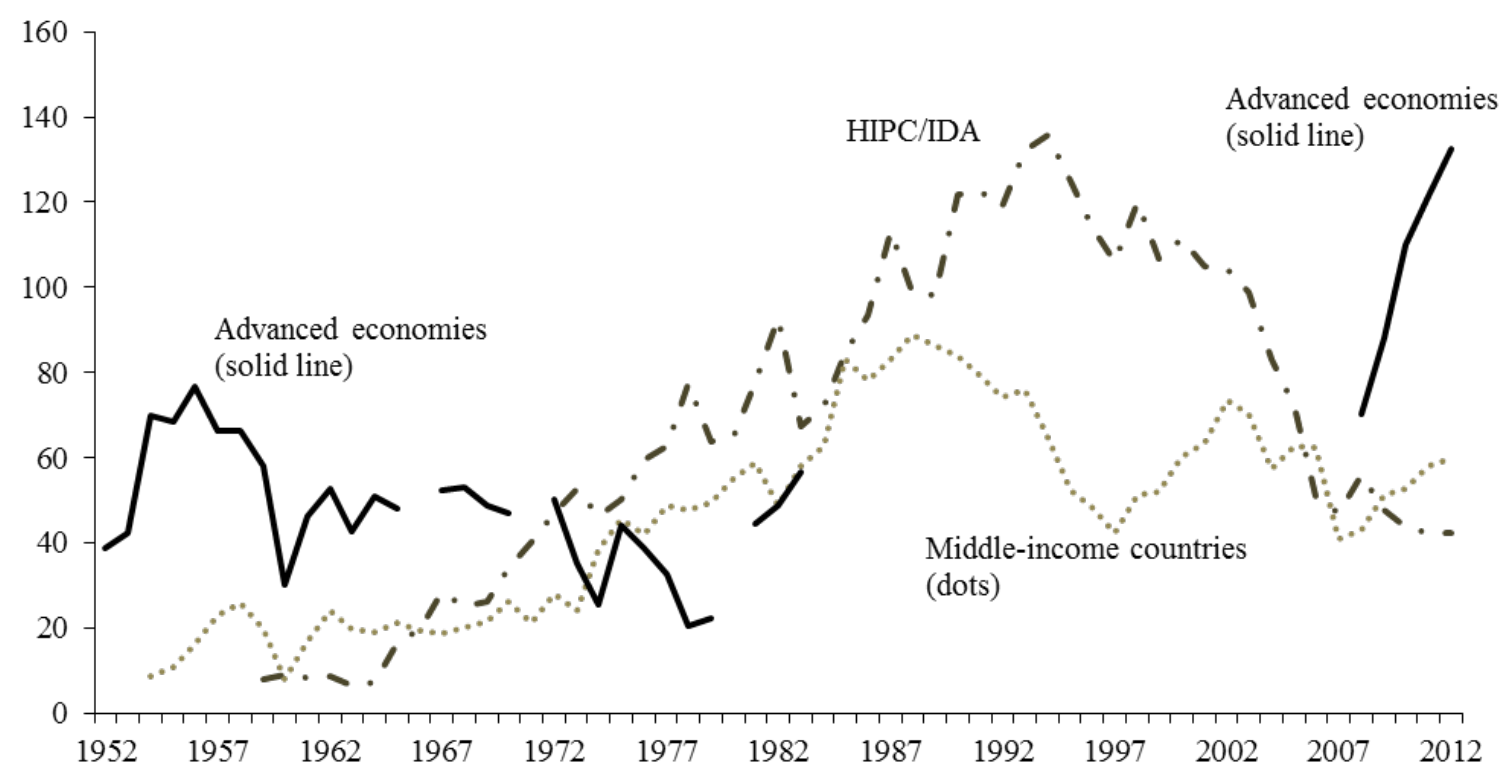

Sources: Gold (1970), International Monetary Fund, Monitoring of Fund Arrangements (MONA) Database and World Economic Outlook, Joyce (2005), Killick (1995), Mody and Saravia (2006), Reinhart and Rogoff (2009), Reinhart and Trebesch (2015), and authors'calculations.

\section{III.4 Implications of the Eurozone Crisis}

The Eurozone crisis was the latest demand "shock" for IMF lending. It had a major impact on the IMF's loan portfolio (see Figures A.2, A.3) and the IMF's perception as a lender of last resort (Moreno 2013, Schadler 2014). Three features of IMF involvement stand out.

First, the crisis in Europe strengthened the tendency towards bigger programs and towards lending to countries with very high levels of debt (Figure 11). This increased the risks incurred by the IMF considerably. Table 1 shows that the recent programs in Greece, Ireland, and Portugal beat records in terms of size in total amounts (and as \% of debtor country GDP). All three countries have a debt/GDP ratio of above 100\%. Moreover, since 2008, several other European countries received major IMF loans, in particular Iceland, Ukraine, and Hungary. As a result, the IMF loans portfolio became highly concentrated in Europe, as shown in Figure 12. As of 2013, almost 80\% of outstanding IMF loans were owed by European countries alone. The scale of concentration is unprecedented in the IMF's history. 
Figure 12. IMF Credit Outstanding - Regional Concentration

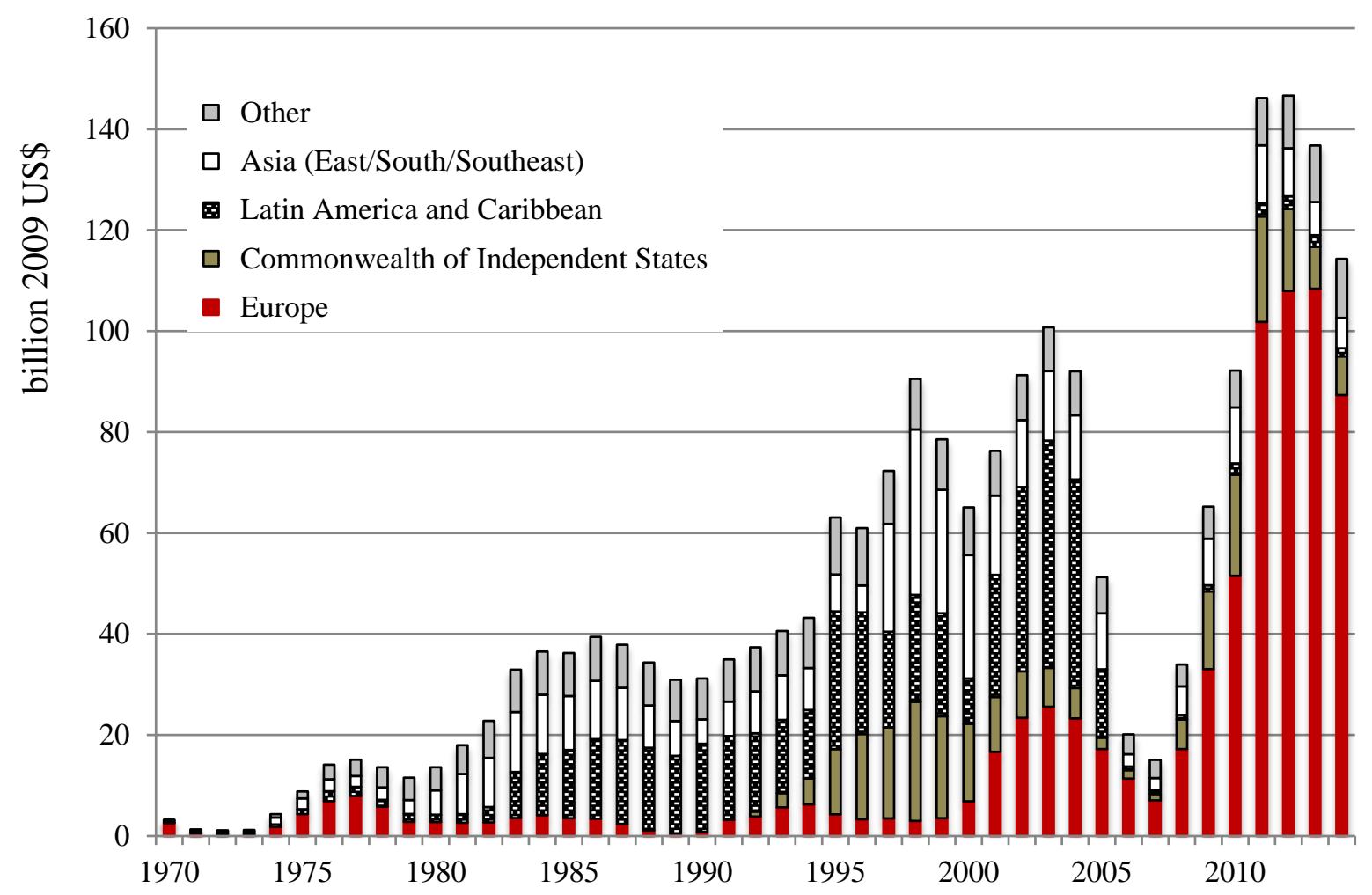

Notes: US\$ figures are converted from SDR using IMF exchange rates. Real values are computed using the GDP deflator by the Federal Reserve Bank of St. Louis (base year: 2009).

Sources: Gold (1970), International Monetary Fund, Monitoring of Fund Arrangements (MONA) Database, Joyce (2005), Killick (1995), Mody and Saravia (2006), and authors'calculations.

Ex-post, we know that some of the European IMF programs did not fail, in the sense that the IMF credits were largely paid back (Iceland, Ireland, and Portugal). In the cases of Greece and Ukraine, which remain large-scale debtors, the jury is still out. However, it seems obvious that, in terms of its loans portfolio, the risks incurred by the IMF after 2008 were larger than ever before.

A second feature of the European crisis is the damage it did to the IMF's reputation, in particular in the case of Greece. Most visibly, the Greek default on IMF loans on June 30, 2015 was a blow to the IMF's seniority status (Greece missed a payment of $€ 1.5$ bn on June 30, 2015 and another payment of $€ 456$ million on July 13, 2015). Greece was the first advanced economy to ever miss an IMF payment. In the past 70 years a total of 23 countries ran into protracted arrears with the IMF, but the large majority of these defaulters were low-income countries or countries suffering from severe war or natural disasters. Defaulting on the IMF is typically a last recourse. As shown by Schlegl, Trebesch 
and Wright (2015), the Fund is at the top of the "pecking order" of sovereign debt repayments, as debtor countries usually default on all other external creditors first, prior to missing any payments towards the IMF. Notably, this was not the case in Greece, which defaulted on the IMF, but continued to repay private bondholders. At the same time, Greece was by far the largest client of the IMF, accounting for 26.6\% of total IMF lending in end-2014.

Figure 13 illustrates how large a full-fledged default by Greece would have been, and compares this possibility to the history of IMF arrears. This episode illustrates just how dangerous it is for a lender of last resort to agree to serial lending to a country with unsustainable debts. Lending into insolvency (especially in large member countries) endangers the IMF's most valuable asset: its seniority. This is especially true because the IMF's seniority is not written in law, but rather a market convention. If market participants and debtor governments start questioning the IMF's seniority status, there is little the IMF can do to enforce its status.

Figure 13. Total Arrears to the IMF 1984-2014 and outstanding Greek IMF loans in 2014 SDR, millions, end of period

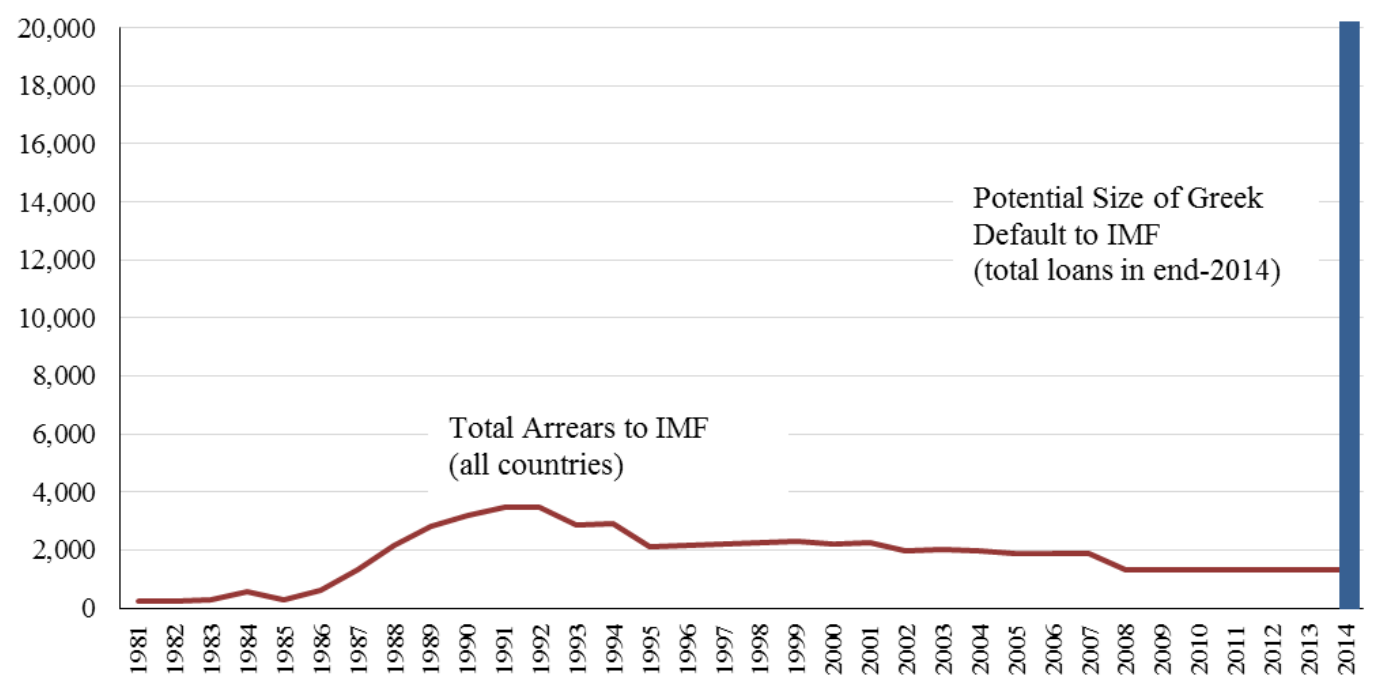

Sources: See Table in Appendix IV.

More generally, the IMF’s management in the Greek crisis has been widely criticized (see Subramanian, 2015, and Mody, 2015), and the Fund has publicly acknowledged mistakes (IMF 2013). In a longer historical perspective, however, this dimension is hardly new, as the institution has come under repeated fire in its handling of past crises (Latin America 1980s, Asia 1997-1998, Russia 1998, Argentina 2001, to name a few). 
The third and maybe most problematic legacy of the Eurozone crisis is the so called "systemic exemption” clause (IMF 2014b), which effectively scrapped the IMF's long-standing rule that no loans should be given to countries with unsustainable debts. The policy authorizes the IMF to lend to any country (even insolvent ones) in case this country poses large risks of systemic financial spillovers. It was introduced in 2010, when the Greek debt burden was no longer evaluated as "sustainable with high probability” by Fund staff (a precondition for grating exceptionally large IMF loans). In response, the IMF altered its lending framework ad hoc, argued that Greece indeed posed severe spillover risks for the Eurozone and the world economy, and, on the same day, granted the country access to IMF loans worth $€ 30$ billion - more than $3000 \%$ of the Greek quota (the largest Fund program ever relative to quota, see IMF 2013). Despite a recent staff proposal to drop the exemption clause, the rule remains in place until this day, meaning that IMF lending into insolvency can continue on a large scale, at least as long as IMF management judges the member country to be of systemic importance. ${ }^{13}$ As a result, the IMF may face larger demands for new loans, including by large emerging markets with heavy debt burdens. Moreover, credibility problems may increase in cases where private creditors are asked to agree to a debt restructuring and share part of the burden in future bailout programs. Such developments may contribute to creditor moral hazard and further undermine the Fund's role as a lender of last resort.

\section{Demand-Driven or Supply-Driven?}

Discussions of the trends and patterns in IMF program lending often fall into two main categories, depending on whether they tend to emphasize demand-driven or supply-driven explanations. In explaining the breadth and timing of the changes in IMF lending documented in this paper, we lean toward a "borrower demand driven" theory of institutional change at the IMF, in which the Fund has redefined the issues it seeks to address and the tools it employs based on the evolving needs of its clientele.

One important demand factor has been the re-globalization of capital markets in the 1980s, which was accompanied by large-scale cross-border capital flows, more episodes of "sudden stops",

\footnotetext{
${ }^{13}$ For a more detailed discussion see Schadler (2013).
} 
more systemic banking crises and more government bailouts of corporate and financial sectors (Kaminsky and Reinhart 1999). ${ }^{14}$ As a result of these trends, the Fund's main activity shifted from mostly trade related problems (then) to mostly capital flow related problems (now). These shifts also became visible in the IMF's organizational structure. . In particular, the experience of the Mexican and East Asian crisis of the 1990s paved the way for the introduction of a new department within the IMF that focused on the financial sector. Moreover, by the late 1990s, the Financial Sector Assessment Program (FSAP) had become a central element of IMF “surveillance," in which it evaluates the economic risks that countries may face.

Another demand factor has been the persistent financing need of poor countries without access to private external capital markets, which in 1987, gave rise to the Enhanced Structural Adjustment Facility (ESAF) program focused on low-interest loans to low-income countries. As noted, a significant share of these programs involve countries with chronic arrears to official borrowers and account for some of the longest (recurring) IMF programs.

An alternative view would characterize the IMF as being “creditor supply-driven,” taking the position that key funders (and the United States in particular) have dictated IMF and used it as an extension of their own treasury ministries. This argument is neither new, nor difficult to understand. As noted in Appendix I, the United States and the major economies of Western Europe have IMF quotas that have traditionally granted them considerable power over IMF decisions.

Indeed, the range of evidence that supports the conclusion that politics plays a role in IMF lending decisions (usually at the country level) is compelling. We have already alluded to some of these findings (for example, the Barro and Lee 2005 study). There are other studies. Thacker (1999), for instance, finds evidence that political factors and voting alignments with the US are significant in explaining the probability of getting an IMF loan (although his results vary across sample periods). Stone (2004) discusses the political economy of IMF loans in Asia. Dreher et al. (2009), for instance,

\footnotetext{
14 "Re-globalization" refers to the fact that the integration of capital markets was substantial in the heyday of the gold standard era (Eichengreen 1992; Obstfeld and Taylor 2004; Reinhart and Rogoff 2009) before two World Wars with the global economic depression of the 1930s in between balkanized global finance.
} 
find systematic evidence that United Nations' Security Council membership reduces the number of conditions included in IMF programs. Another recurring critique is whether the use and character of the conditions that the IMF places on its loans (as well as the rigor with which such conditions are enforced) is unduly influenced by the objectives of key lenders. Jeffrey Sachs at the time of the Asian crisis, 1997-1998 was a vocal proponent of this view (Sachs 1998), while Feldstein (1998) is explicit about this problem in the case of Korea. More systematic evidence comes from Dreher and Jensen (2007), suggesting that closer US allies face less strict IMF conditions.

In a related vein, the issue of political control over the IMF has been also been evolving. For example, China's current quota is less than one-quarter of that of the United States even though by 2014 its share in world GDP (adjusted for purchasing power differentials, as reported by the IMF's World Economic Outlook) reached approximately the same as that of the United States. The China-US split on this issue is much broader (and much older), as it represents the tension between the advanced and developing country membership within the IMF (which was expressed as North versus South in an earlier literature). IMF quotas, with their implications for voting power within the institution and the quantity of loans that can be received, are reviewed infrequently. There has been proposal on the table since 2010 for resetting the IMF quotas. The proposal would roughly double the size of the quotas —and thus double the lending power of the IMF, but it would also diminish the relative power of the United States and Western Europe. China would become the country with the third-largest quota and voting power at the IMF, and Brazil, India, and Russia would all be in the ten largest countries by voting power. ${ }^{15}$. However, the change cannot occur without the support of the United States, which has so far declined to do so.

In sum, while we would emphasize a "demand driven" interpretation for general or aggregate trends in IMF lending, our view does not preclude political factors from playing a significant role in the design or implementation of IMF lending programs for individual countries, as suggested by much of the evidence.

\footnotetext{
${ }^{15}$ For more details on the proposed change, see http://www.imf.org/external/np/exr/facts/quotas.htm.
} 


\section{Conflicting Objectives}

During the decades since the IMF was founded (in 1945), a clear disconnect has emerged between the institution's original mandate and its modern operations. Indeed, the gap between mandate and operations appears to have widened over time. The original mandate of the IMF focused on temporary lending when liquidity was tight and balance of payments support was needed. Despite those intentions, we have documented here a number of patterns which suggest that an alternative mission has taken root: 1) about one-quarter of the member countries have been engaged in an IMF program more than half of the years since becoming a member; 2) 66 out of 188 member countries have had consecutive IMF program spells that last somewhere between 10 and 30 years; 3) since the 1980s, the share of IMF programs involving a sovereign that is in default, restructuring, or arrears has oscillated between 40 and 70 percent; 4) IMF lending in the post- 2008 period to high-income countries in Europe has re-enforced the prior ongoing trends toward larger and longer programs that are entangled with issues of sovereign debt.

In explaining the reasons behind this change, we lean toward an interpretation in which the Fund has redefined the issues it seeks to address and the tools it employs based on the evolving challenges of its members. A more negative interpretation is that the trends documented here are evidence of mission creep at the IMF, in part in response to increased competition with the World Bank and other development institutions. Indeed, the Asian Infrastructure Development Bank, led by a political push from China, is sometimes seen as a threat to the IMF’s relevance. Along another margin, some studies have suggested that the IMF often competes with private capital markets.

Our concern is that the IMF’s increasing involvement in chronic debt crises and in development finance may make it harder to focus on its original mission. While the modern demands on the IMF with nearly 200 members are more diverse than ever before, the old or original needs as defined in the Articles of Agreement remain as compelling as ever. It is true that classic balance-of-payments problems may no longer arise as frequently as they once did, because exchange rates are no longer as likely to be fixed or predetermined. However, de jure exchange rate arrangements that promise floating exchange rates are often more flexible on paper than they are in practice; fear of floating has diminished but not disappeared (Levy-Yeyati and Sturzeneger 2007; Ilzeztki, Reinhart and Rogoff 2016). 
There are further reasons why an international lender of last resort remains indispensable. The high levels of international reserves that we observe today should not be taken for granted. International commodity prices can change abruptly and deteriorate over long periods, as do global financial conditions. Most developing or emerging economies (and not a few advanced ones) have large stocks of debts in foreign currency. Moreover, a domestic lender of last resort faces limitations in emerging markets, particularly those that are highly dollarized (Calvo 2006). In the past, the US Federal Reserve has shown a remarkable willingness to provide dollar liquidity in crisis times, for example when markets froze in 2009. Yet, the Fed's role and mandate are first and foremost domestic. Finally, there are numerous global and regional development agencies, but the world lacks a global central bank.

The inherent conflict faced by the IMF is between strengthening its role as an international lender of last resort and the demands of many member countries for serial lending, resulting in repeated programs and a perpetual state of debt "ever-greening.” A usual concern in this context is that countries will be tempted to over-borrow, if the terms of repayment are so elastic (both the IMF and the debtors have incentives for ever-greening their loans). However, the point we would like to emphasize instead deals with signaling and stigma.

Many countries appear to welcome (in principle at least) access to liquidity in times of financial stress. The IMF answer is to offer contingent credit lines, which can supplement the self-insurance of countries provided by their holdings of international foreign exchange reserves. However, an international discount window faces many of the same problems of discount window facilities of domestic central banks. In a domestic setting, banks often shy away from approaching a central bank’s discount window for fear that temporary illiquidity will be mistaken for insolvency by fellow market participants (for discussions of this issue, see Board of Governors of the Federal Reserve 2015; European Central Bank 2015; BIS 2014). As one example, an important object lesson in the Federal Reserve's history comes from the crisis of Continental Illinois National Bank and Trust Company in 1984. In order to meet the demands created by bank runs, Continental Illinois borrowed heavily from the discount window in 1984. The association of the discount window with a failing institution set a precedent of adverse signaling that subsequently led other banks to avoid the discount window, for fear they may be deemed as similarly troubled institutions. A policy instrument was damaged and lost. 
It seems plausible that countries may worry about stigma in a manner similar to banks.

The fact that so much of IMF lending in recent decades is longer term and connected to longrun solvency problems may taint all of its lending. The importance of appearances and signaling, especially how these factors may manifest themselves in times of stress and confusion, should not be underrated. If an IMF program carries a signal of insolvency and is categorically associated with other chronic problems, engaging in a program carries a risk of sending a negative signal about a country’s solvency.

If removing development finance and insolvent nations from IMF lending programs is not in the cards, there may at least be merit in more deliberately separating lender of last resort activities from the remainder of what the Fund does. In recent years, the IMF has shown efforts to move in this direction. It introduced several new program lines that tilt (albeit broadly) in the direction of behaving like a central bank discount window — that is, being willing to extend a substantial volume of credit on short notice. First, the Rapid Credit Facility (RCF), which seeks to provide quick loans with limited conditions to low-income countries facing a balance of payments crisis. Second, the Flexible Credit Line (FCL), enacted in 2009, which has the specific goal of reducing the risk of stigma. FCL loans are granted for crisis-prevention and crisis-mitigation in more stable economies, i.e. for countries with very strong policy frameworks and before the economy is at severe risk. Third, the Precautionary and Liquidity Line (PLL) is aimed at countries with essentially sound economic fundamentals but with a limited number of vulnerabilities which disqualifies them from using the Flexible Credit Line.

At least so far, these discount-window-like programs have not drawn much interest from potential borrowers. The FCL has only had three applicants (Colombia, Mexico, and Poland), while the PLL has been arranged in two cases only (in the Former Yugoslav Republic of Macedonia and Morocco). Perhaps the limited impact of these programs is due to the fact that issues of stigma remain. This danger of being unable to perform a lender of last resort function because of straying from its original mission is most likely the fuel behind the recommendation of Calomiris and Meltzer (1999) that the IMF act only as lender of last resort and only to countries that meet certain prerequisite standards in banking. 
In this journal more than a decade ago, Fischer (1999) touched upon many of the central issues related to the need for an international lender of last resort, particularly in connection with reducing the intensity of financial crises and limiting contagion. We agree with Fischer that a modest element of crisis avoidance may be within reach if there is a more effective lender of last resort. Furthermore, we recognize the IMF's potential role in mitigating the impact of crises on economic development and on long term growth (on crisis costs see Cerra and Saxena, 2008, and Reinhart and Reinhart 2010, 2015). ${ }^{16}$

\section{Concluding Observations: What Lies Ahead?}

In the last few years, while advanced economy borrowing from the IMF has reached historic highs, emerging markets have mostly abstained from IMF borrowing. This has much to do with the favorable external environment that emerging markets faced during much of the past decade: US interest rates were low, declining, and mostly negative after adjusting for inflation; commodity prices were rising markedly; China’s investment-led record growth rates fueled the appetite for primary commodity exports; bleak asset returns in advanced economies set off the eternal quest for yields among global investors, favoring emerging markets as an asset class. Good policies helped, too: unlike in prior commodity price booms like the 1970s, many developing country governments managed to avoid heavily pro-cyclical fiscal policies.

But the era of tranquility for emerging markets appears to have ended (at least temporarily). The risks are many. During the last few years, firms and banks in emerging market economies have increasingly succumbed to the temptation of borrowing at low international interest rates at a time during which their currencies were either stable or appreciating against the dollar. Current account deficits have reappeared for many of these countries, along with domestic credit booms and currency overvaluation. Moreover, growth began to slow and the US Federal Reserve announced its plans to gradually withdraw from its exceptionally accommodative policies of last few years during the spring of

\footnotetext{
${ }^{16}$ Using a sample spanning 1870-2014, Reinhart and Reinhart (2015) document that crises are typically associated with lower medium-term growth. Given that the forces for convergence of income across countries are estimated to be slow, an economy that goes off track at the time of a financial crisis may well experience long-lived consequences for its relative economic development—consequences that could have been mitigated by an active and able international lender of last resort.
} 
2013. Since then, a sharply appreciating US dollar coupled with significant domestic currency depreciations in many emerging markets have increased external debt burdens.

It is precisely in such an unsettling environment for emerging markets that the IMF may face another wave of demands on its resources. At such a juncture, it appears particularly important that the IMF strengthens its international lender of last resort capabilities and works towards reducing the stigma of IMF lending. The legacy of the recent IMF lending in Europe raises the question of whether the IMF's next round of programs will ratchet up to the 10-16 percent of GDP, too. If emerging market economies and/or advanced economies in crisis situations were to need and request the same program scale going forward, this would imply more risks for the IMF portfolio, and surely increase the likelihood that the IMF ends up lending into insolvency. A good starting point to mitigate these risks would therefore be to strictly apply the debt sustainability criteria that IMF policies prescribe. Serial lending to low-income countries and countries with severe debt sustainability problems moves the functioning of the institution quite close to that of development agencies, which is an increasingly crowded field. In our view, the only way to preserve the unique status and the seniority of the IMF is to assure that its lending focuses on the task of providing liquidity quickly in response to short-term financial crises — that is, acting as a lending source of last resort — the central bank to central banks. 


\section{References}

Arslanalp, Serkan and Takahiro Tsuda. 2014. "Tracking Global Demand for Advanced Economy Sovereign Debt.” IMF Economic Review, 62(3), pp. 430-464.

Bank of International Settlements. 2014. Re-Thinking the Lender of Last Resort. BIS Papers No 79.

Barro, Robert J. and Jong-Wha Lee. 2005.”IMF Programs: Who is Chosen and What are the Effects?” Journal of Monetary Economics, 52(7), pp. 1245-1269.

Beers, David T. and Jean-Sébastien Nadeau. 2015. "Database of Sovereign Defaults. ” Bank of Canada Technical Report No. 101.

Behrman, Greg. 2007. "The Most Noble Adventure: The Marshall Plan and the Reconstruction of PostWar Europe .” London: Aurum Press Ltd.

Board of Governors of the Federal Reserve System. 2015. "The Federal Reserve Discount Window.”

Bordo, Michael D. and Harold James. 2000. "The International Monetary Fund: Its Present Role in Historical Perspective.” NBER No. w7724.

Boughton, James M. 2001. “Silent Revolution: The International Monetary Fund, 1979-89.” Washington D.C.: IMF Press.

Boughton, James M. 2012. Tearing Down Walls: The International Monetary Fund 1990-1999. Washington D.C.: IMF Press.

Boughton, James M. and Sarwar Lateef, 1995. Fifty Years After Bretton Woods: The Future of IMF and the World Bank, IMF Press.

Bulow, Jeremy and Kenneth Rogoff. 1990. "Cleaning Up Third World Debt Without Getting Taken to the Cleaners.” The Journal of Economic Perspectives, 4(1), pp. 31-42.

Bulow, Jeremy, and Kenneth Rogoff. 2005. “Grants versus loans for development banks.” American Economic Review 95(2), pp. 393-397.

Bird, Graham, Mumtaz Hussain, and Joseph P. Joyce. 2004. "Many Happy Returns? Recidivism andthe IMF.” Journal of International Money and Finance, 23(2), pp. 231-251.

Calomiris, Charles W. and Allan H. Meltzer. 1999. "Reforming the IMF." Unpublished, New York: Columbia Business School.

Calvo, Guillermo A. 2006. "Monetary Policy Challenges in Emerging Markets: Sudden Stop, Liability Dollarization, and Lender of Last Resort” NBER No. w12788.

Cerra, Valerie and Sweta Chaman Saxena. 2008. "Growth Dynamics: The Myth of Economic Recovery.” American Economic Review, 98(1), pp. 439-457.

Claessens, Stijn M.,Kose, Ayhan and Marco E. Terrones. 2009. "What Happens During Recessions, Crunches and Busts?” Economic Policy, 24(60), pp. 653-700. 
Cooper, Richard. 1971. “Currency Devaluation in Developing Countries.” In G. Ranis, Government and Economic Development, New Haven: Yale University Press.

Cruces, Juan J. and Christoph Trebesch. 2013. "Sovereign Defaults: The Price of Haircuts.” American Economic Journal: Macroeconomics, 5(3), pp. 85-117.

Dell'Ariccia, Giovanni, Detragiache, Enrica, and Raghuram Rajan. 2008. “The Real Effect of Banking Crises.” Journal of Financial Intermediation, 17(1), pp. 89-112.

De Vries, Margaret Garritsen, 1976. The International Monetary Fund, 1966-1971: Narrative. Vol. 1. International Monetary Fund.

Díaz-Alejandro, Carlos F. 1983. "Stories of the 1930s for the 1980s” In Financial Policies and the World Capital Market: The Problem of Latin American Countries, Chicago edited by Pedro A. Armella, Rudiger Dornbusch, and Maurice Obstfeld, Chap. 1. University of Chicago Press.

Díaz-Alejandro, Carlos F. 1984. "Latin American Debt: I Don’t Think We Are in Kansas Anymore.” Brookings Papers on Economic Activity, 2, pp. 335-403.

Diaz-Cassou, J., Erce, A., and J. Vazquez-Zamora (2008), “The Role of the IMF in Sovereign Debt Restructurings: Implications for the Lending Into Arrears Policy.” Bank of Spain Working Paper 805.

Dreher, Axel and Nathan Jensen. 2007. "Independent Actor or Agent? An Empirical Analysis of the impact of US interests on IMF Conditions.” Journal of Law \& Economics, 50(1), pp. 105-124.

Dreher, Axel, Sturm, Jan-Egbert and James Raymond Vreeland. 2009. "Global Horse Trading: IMF Loans for Votes in the United Nations Security Council,” European Economic Review, 53(7), pp.742-757.

Economist. 2008. “The IMF Downsizes: It's Mostly Firing.” February 7.

Economist. 2009. “The IMF: Battling Stigma. The IMF is in Search of a Role, and a Happier Reputation”, March 26.

Edwards, Sebastian. 1989. "The International Monetary Fund and the Developing Countries: A Critical Evaluation.” Carnegie-Rochester Conference Series on Public Policy, 31, pp. 7-68.

Eichengreen, Barry. 1992. Golden Fetters: The Gold Standard and the Great Depression 1919-1939, Oxford University Press.

Erce, Aitor. 2013. "Sovereign Debt Restructurings and the IMF: Implications for Future Official Interventions.” Federal Reserve Bank of Dallas Working Paper No. 143.

European Central Bank. 2015. “ELA Procedures.”

Feldstein, Martin. 1998. “Refocusing the IMF.” Foreign Affairs, 77(2), pp. 20-33.

Fischer, Stanley.1999 “On the Need for An International Lender of Last Resort.” Journal of Economic Perspectives, 13(4), pp. 85-104.

Gold, Joseph. 1970. "Stand-by arrangements of the International Monetary Fund." Washington D.C.: International Monetary Fund. 
Gourinchas, Pierre-Olivier and Maurice Obstfeld. 2012. "Stories of the Twentieth Century for the Twenty-First.” American Economic Journal: Macroeconomics, 4(1), pp. 226-65.

Horsefield, John Keith, and Margaret Garritsen De Vries, eds, 1969. The International Monetary Fund, 1945-1965: Twenty Years of International Monetary Cooperation. Vol. 1.

International Monetary Fund. 1999. “The IMF's Enhanced Structural Adjustment Facility (ESAF): Is It Working?” September, https://www.imf.org/external/pubs/ft/esaf/exr/.

International Monetary Fund. 2002. "Evaluation of Prolonged Use of IMF Resources." Internal Evaluation Office.

International Monetary Fund. 2013. "Greece: Ex Post Evaluation of Exceptional Access under the 2010 Stand-By Arrangement.” IMF Country Report No. 13/156.

International Monetary Fund. 2014. "Review of Flexible Credit Line, Precautionary and Liquidity Line, and Rapid Financing Instrument.“ January 2014, IMF Policy Paper.

International Monetary Fund. 2014. "The Fund’s Lending Framework and Sovereign Debt - Preliminary Considerations.” Washington D.C.: IMF

International Monetary Fund. World Economic Outlook, various issues.

Ilzeztki, Ethan, Carmen M. Reinhart and Kenneth Rogoff. 2016. "Exchange Rate Arrangements Entering the 21st Century: Which Anchor Will Hold?" Harvard University, mimeo.

Jordà, Òscar, Moritz Schularick and Alan M. Taylor. 2011. "When Credit Bites Back: Leverage, Business Cycles, and Crises.” Journal of Money, Credit, and Banking, 45(2), pp. 3-28.

Joyce, Joseph. 2005. “Time Past and Time Present: a Duration Analysis of IMF Program Spells.” Review of International Economics, 13(2), pp. 283-297.

Kaminsky, Graciela L., and Carmen M. Reinhart, 1999. "The Twin Crises: the Causes of Banking and Balance-of-Payments Problems.” American Economic Review, 89, pp. 473-500.

Killick, Tony, 1995. "IMF Programmes in Developing Countries: Design and Impact.” New York: Routledge.

Krueger, Anne O. 1978. “Liberalization Attempts and Consequences.” Cambridge, MA: Ballinger.

Krueger, Anne O. 1998. "Whither the World Bank and the IMF?" Journal of Economic Literature, 36, No. 4 (Dec., 1998), pp. 1983-2020

Kindleberger, Charles P. 1978. "Manias, Panics and Crashes: A History of Financial Crises.” New York: Wiley.

Levy-Yeyati, Eduardo Levy, and Federico Sturzenegger. 2007. "Fear of Appreciation.” World Bank Policy Research Working Paper Series, No. 4387.

Mody, Ashoka, and Diego Saravia. 2006. "Catalysing Private Capital Flows: Do IMF Programmes Work as Commitment Devices?” Economic Journal, 116(513), pp. 843-867.

Mody, Ashoka. 2015. “In Bad Faith.” Bruegel Blog Post, July $3^{\text {rd }}$. 
Moreno, Pablo. 2013. “The Metanorphosis of the IMF (2009-2011).” Bank of Spain Working Paper 78.

Nowzad, Bahram, 1981. “The IMF and Its Critics,” Princeton Essays in International Finance Number 146, December.

Obstfeld, Maurice, and Alan M. Taylor. 2004. "Global Capital Markets: Integration, Crisis, and Growth.” Japan-U.S. Center Sanwa Monographs on International Financial Markets, Cambridge: Cambridge University Press.

Reinhart, Carmen M. and Kenneth S. Rogoff. 2009. “This Time Is Different: Eight Centuries of Financial Folly.” Princeton: Princeton University Press.

Reinhart, Carmen M. and M. Belen Sbrancia. 2015. “The Liquidation of Government Debt.” Economic Policy, 30(82), pp. 291-333.

Reinhart, Carmen M. and Vincent R. Reinhart. 2010. “After the Fall.” in Proceedings, Federal Reserve Bank of Kansas City Economic Policy Symposium, Macroeconomic Challenges: The Decade Ahead, 2010, pp. 17-60.

Reinhart, Carmen M. and Vincent R. Reinhart. 2015. "Financial Crises, Development, and Growth: A Long-term Perspective.” World Bank Economic Review, 29 (1), pp. 1-24.

Reinhart, Carmen M. and Christoph Trebesch. 2015. "Sovereign Debt Relief and its Aftermath." Forthcoming, Journal of the European Economic Association.

Rose, Andrew K. 2005. "One Reason Countries Pay Their Debts: Renegotiation and International Trade," Journal of Development Economics, 77 (1)), pp. 189-206.

Sachs, Jeffrey. 1998. "The IMF and the Asian Flu.” The American Prospect no. 37.

Schadler, Susan. 2013. "Unsustainable Debt and the Political Economy of Lending: Constraining the IMF’s role in Sovereign Debt Crises”, CIGI Paper No 19.

Schadler, Susan. 2014. "The IMF's Preferred Creditor Status: Does it still Make Sense after the Euro Crisis?” CIGI Paper No 37.

Schlegl, Matthias, Trebesch, Christoph, and Mark. L.J. Wright 2015. “The Seniority Structure of Sovereign Debt.” unpublished paper.

Subramanian, Arvind. 2015. “How The IMF Failed Greece.” Project Syndicate Column, August 13.

Standard and Poor's. 2015. Default, Transition, and Recovery: 2014 Annual Sovereign Default Study and Rating Transitions. New York: Mc Graw Hill.

Stone, Randall W. 2004. "The Political Economy of IMF Lending in Africa.” American Political Science Review, 98(4), pp. 577-591.

Thacker, Strom C. 1999. “The High Politics of IMF Lending.” World Politics, 52, pp. 38-75.

World Bank. 2015. “International Debt Statistics”, Washington DC: The World Bank. 


\section{Appendix I: IMF structure}

A country that joins the IMF is given a "quota," which is the amount that must be paid by the country to the IMF upon joining. The total of all national quota is at present around \$330 billion (although the IMF denominates the total in "Special Drawing Rights” whose value changes with movements in exchange rates). The main factor determining the quota is the size of a country's GDP, but a country's openness to trade, economic variability and size of international reserves may also play a role. Up to three-quarters of a nation's quota can be paid in its own currency, while the rest must be paid in "hard" currencies that are widely accepted in the global economy like the US dollar, the euro, and the yen. Quotas determine voting rights within the IMF. Because quotas are linked to GDP, it follows that during the history of the IMF, the United States and the major economies of western Europe have largely controlled the decision-making apparatus: for example, the United States has a large enough share of total votes that it can exercise veto power over any substantial IMF decisions, while the Managing Director of the IMF has always been a European. What a country can borrow from the IMF is typically in the range of 200 to 600 percent of its quota, depending on the situation, although as we will see the recent IMF loans in Europe have greatly exceeded this threshold. For a basic overview of the quota system, the IMF website offers a useful starting point: http://www.imf.org/external/np/exr/facts/quotas.htm. 


\section{Appendix II: A Note on Official debt}

As noted, the sheer magnitudes of the IMF lending to periphery Europe is on a different scale from most past metrics in terms of the real dollar amounts, its share of IMF quotas, and its size relative to the GDP of the borrowers. ${ }^{17}$ However, there is another important dimension in which the recent episode stands out from experience. Other official lending to Greece, Ireland and Portugal from newlycreated post-crisis facilities, predominantly the European Financial Stabilization Mechanism (EFSM); and the European Financial Stability Facility (EFSF) has also soared. Indeed, Greek, Irish and Portugese debt is now largely in the hands of official creditors, as carefully documented by Arslanalp and Tsuda (2014) and shown in Figure 7. This is strikingly at odds with the experience of most middleincome emerging markets and more similar to the low-income countries that seldom (if ever) had access to international private capital markets.

In the modern era, debts to the official sector of those magnitudes have only been associated with the two World Wars and their immediate aftermath. As documented in Reinhart and Trebesch (2015), most (if not all) of the WWI official debt of the advanced economies (of comparable magnitudes) went into default in the summer of 1934 and was never repaid. ${ }^{18}$

\footnotetext{
${ }^{17}$ Periphery here also includes emerging Europe.

${ }^{18}$ The notable exception was Finland, which fully repaid its obligations to the United States.
} 
Figure A.1. Holders of Advanced Economy Government Debt, 2004-2014Q2 (components in percent; total in percent of GDP)
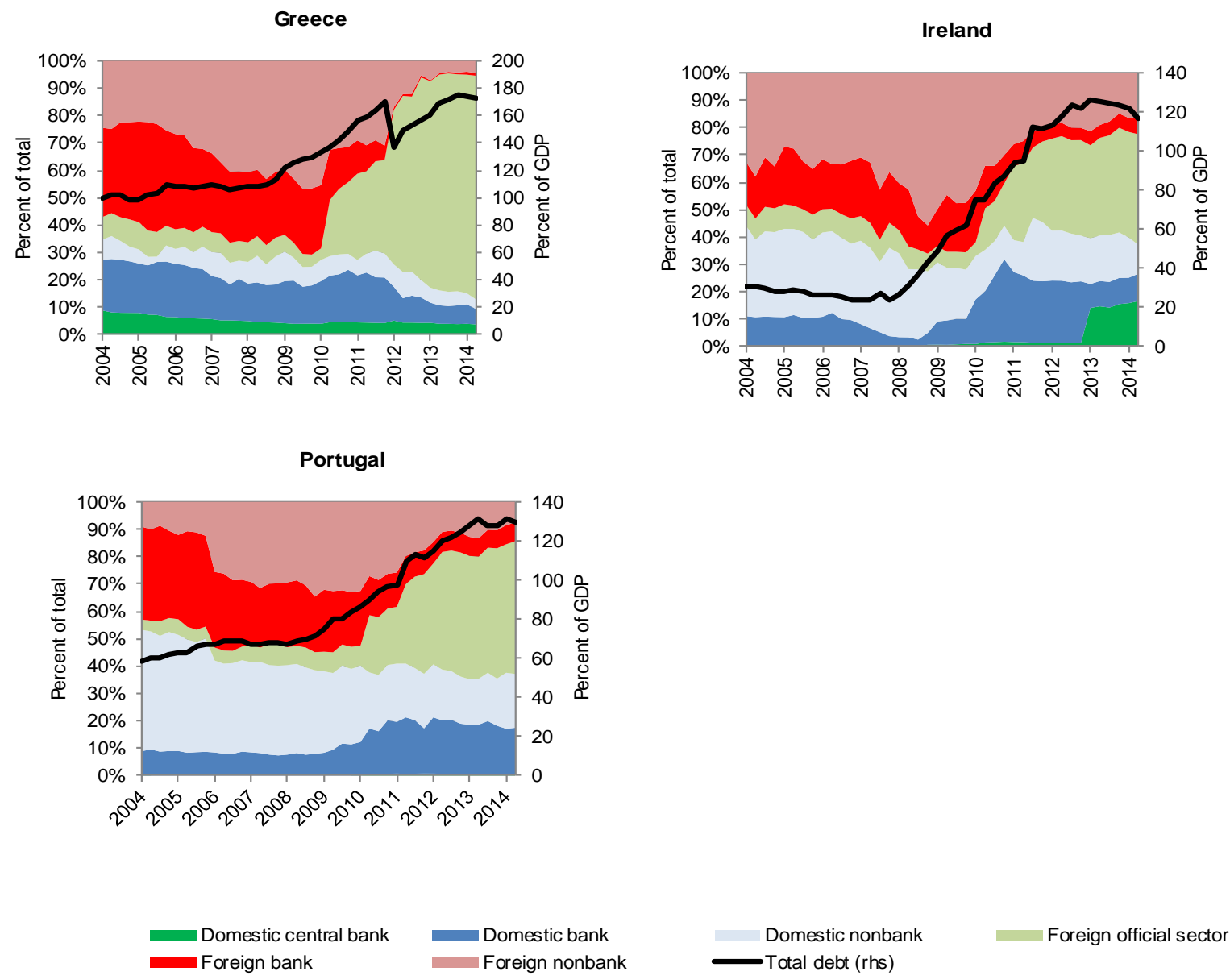

Source: Arslanalp and Tsuda (2014), https://www.imf.org/external/pubs/cat/longres.aspx?sk=40135.0 


\section{Appendix III Supplementary material on IMF program duration}

We suggest that these differences in the underlying problems faced by IMF membership over time influenced important features of IMF programs in terms of their duration, recurrence (serial IMF programs), and their size (relative to both the size of the economy and to their respective IMF quotas). The selected country profiles presented in Figures A.2 and A.3, complement the evidence discussed in Section III. As A.2 highlights for the advanced economies, IMF programs prior to the 1980s (on the whole) were shorter and less recurring (with the exception of the UK) than the programs of more modern vintage in many emerging and developing economies (Figure A.3). The high incidence of default/restructuring of external debt that has accompanied many of the emerging market cases across nearly all regions (for instance, Ghana, Peru, and Vietnam) is, no doubt, connected the different modalities of the IMF interventions. Some of these programs had their origins in the reversal of favorable external factors, as real interest rates climbed in the early 1980s, commodity prices crashed and external financing became difficult, if not impossible, for many sovereigns 
Figure A.2. Years under IMF Programs: 26 Advanced Economies, 1950-20

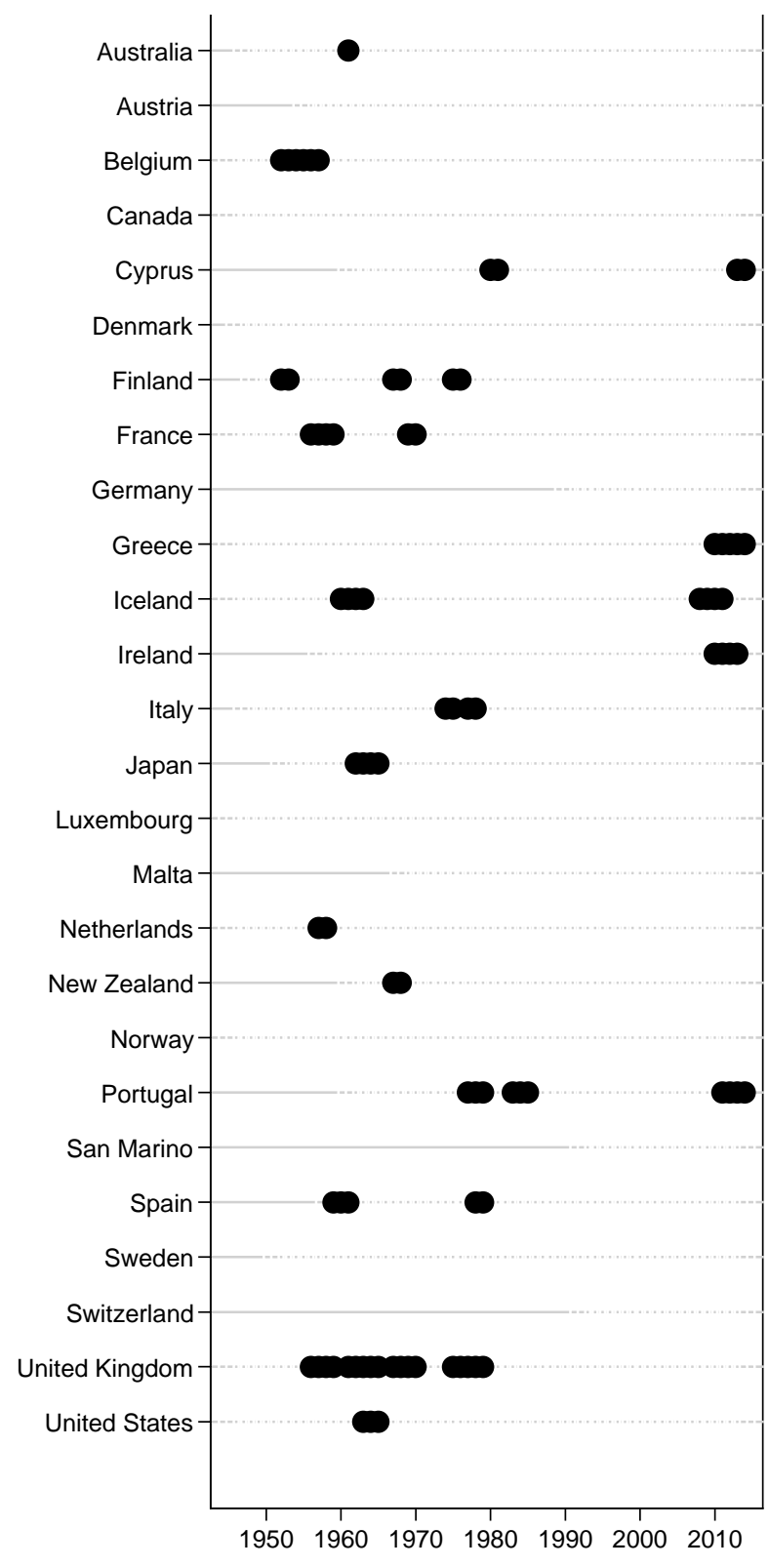

Sources: Gold (1970), International Monetary Fund, Monitoring of Fund Arrangements (MONA) Database, Joyce (2005), Killick (1995), Mody and Saravia (2006). 
Figure A.3. Serial Dependence - Years under IMF Programs 1950-2013

Panel a: Selected Emerging Markets

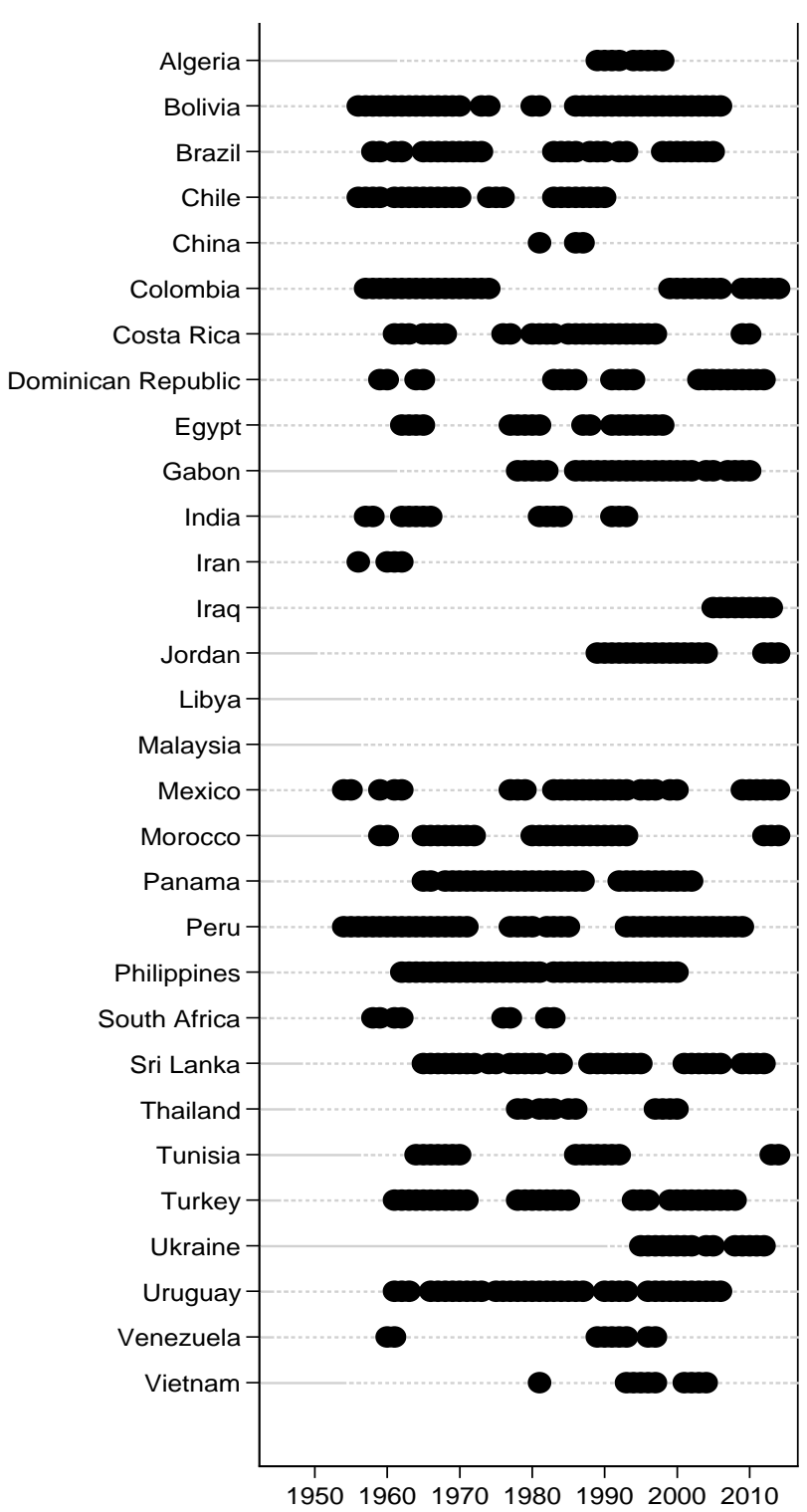

Panel b: Selected Low Income Countries

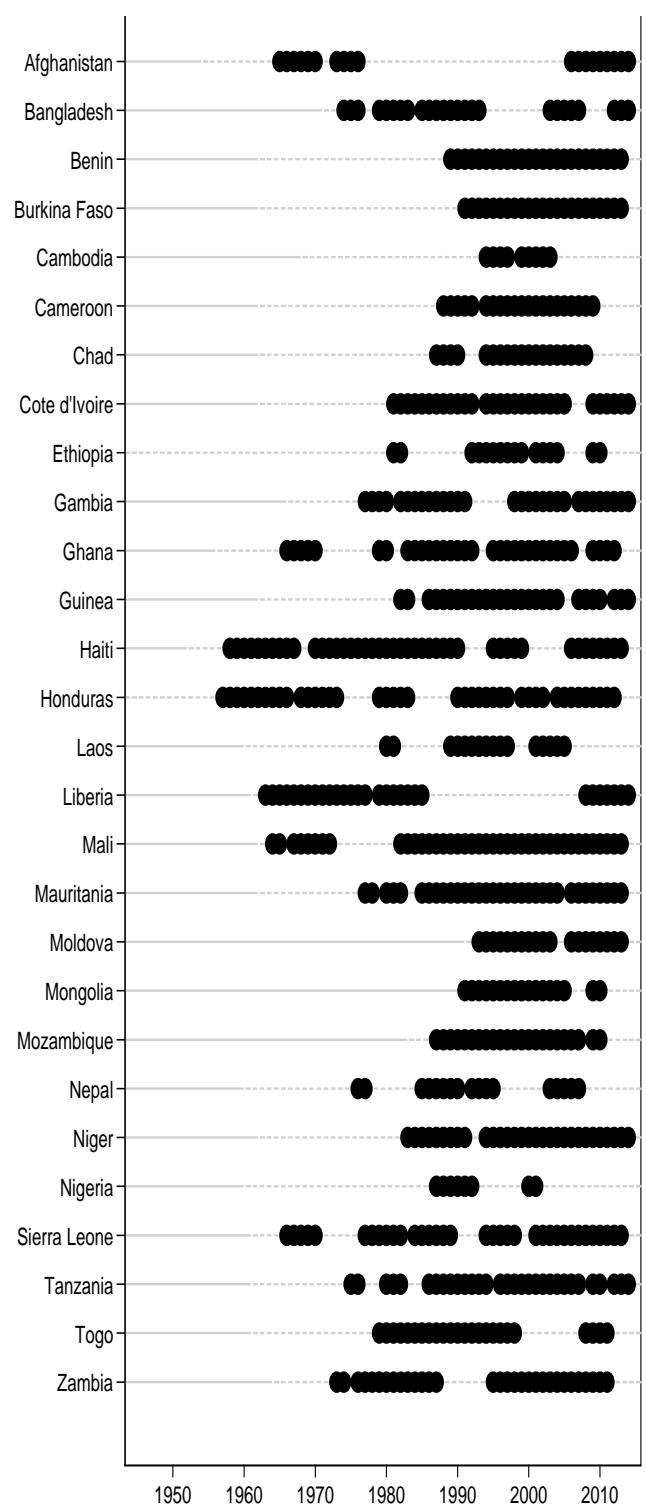

Sources: Gold (1970), International Monetary Fund, Monitoring of Fund Arrangements (MONA) Database, Joyce (2005), Killick (1995), Mody and Saravia (2006). 


\begin{tabular}{|c|c|c|c|c|c|}
\hline Country & $\begin{array}{l}\text { Years with arrears to } \\
\text { the IMF }\end{array}$ & $\begin{array}{l}\text { Declared } \\
\text { Ineligible for } \\
\text { IMF Lending? }\end{array}$ & $\begin{array}{l}\text { Declaration } \\
\text { of Non- } \\
\text { Cooperation? }\end{array}$ & $\begin{array}{l}\text { Suspension of } \\
\text { Voting } \\
\text { Rights? }\end{array}$ & $\begin{array}{l}\text { Compulsory } \\
\text { withdrawal? }\end{array}$ \\
\hline Afghanistan & $1996-2003$ & & & & \\
\hline Bosnia and Herzegovina & 1992-1995 & & & & \\
\hline Cambodia & $1975-1993$ & Yes, in 1978 & & & \\
\hline Central African Republic & 1993-1994 & & & & \\
\hline Congo, Dem. Rep. & 1988, 1991-2002 & Yes, in 1991 & Yes, in 1992 & Yes, in 1994 & \\
\hline Cuba & $1959-1964$ & Initiated in 1963, & but Cuba withdr & raws from the $F$ & und in 1964 and repays \\
\hline Egypt & 1967-1968 & & & & \\
\hline Gambia & $1985-1986$ & & & & \\
\hline Guyana & 1983-1990 & Yes, in 1985 & & & \\
\hline Haiti & 1988-1989, 1991-1994 & & & & \\
\hline Honduras & $1987-1990$ & Yes, in 1989 & & & \\
\hline Iraq & $1991-2004$ & & & & \\
\hline Liberia & $1985-2008$ & Yes, in 1986 & Yes in 1999 & Yes, in 2003 & \\
\hline Panama & 1988-1992 & Yes, in 1989 & & & \\
\hline Peru & 1985-1993 & Yes, in 1986 & & & \\
\hline Serbia & 1993-2000 & & & & \\
\hline Sierra Leone & 1985, 1987-1994 & Yes, in 1988 & & & \\
\hline Somalia & 1987-today & Yes, in 1988 & & & \\
\hline Sudan & 1984-today & Yes, in 1986 & Yes, in 1990 & Yes, in 1993 & Initiated in 1994, but suspended \\
\hline Tanzania & 1985-1986 & & & & \\
\hline Vietnam & 1984-1993 & Yes, in 1985 & & & \\
\hline Zambia & 1986-1994 & Yes, in 1987 & & & \\
\hline Zimbabwe & 2001-today & Yes, in 2001 & Yes, in 2002 & Yes, in 2003 & $\begin{array}{l}\text { Initiated in 2003, but suspended } \\
\text { in } 2006 \text { due to repayments }\end{array}$ \\
\hline
\end{tabular}

Notes: The IMF has an established procedure to react to protracted arrears on its loans. The punishment measures range from declaring a country ineligible for additional IMF leinding, to a declaration of noncooperation (which implies a halt of technical assistant programs, for example), to a suspension of voting rights, and, most drastically, a procedure to prepare a compulsory withdrawal from the IMF (this has never actually occurred, countries like Cuba left voluntarily and fully settled their arrears eventually). For details, see - IMF 2012. "Review of the Fund's Strategy on Overdue Financial Obligations” (link below)

Sources used in this table:

- U. S. Government Accountability Office, 1999. "International Monetary Fund: Observations on the IMF's Financial Operations”, Appendix IV - "Arrears by Country since 1983”

- Boughton (2001), Chapter 16. "Digging a Hole, Filling It In: Payments Arrears to the Fund" https://www.imf.org/external/pubs/ft/history/2001/

- Boughton (2012). Tearing Down Walls. The International Monetary Fund 1990-1999, Chapter 16 "Carrots and Sticks: Safeguarding the Fund's Resources" https://www.imf.org/external/pubs/ft/history/2012/

- IMF 2012. "Review of the Fund's Strategy on Overdue Financial Obligations" https://www.imf.org/external/np/pp/eng/2012/082012.pdf 


\begin{tabular}{|c|c|c|}
\hline Variable & Coverage & Sources \\
\hline IMF programs & 1952-2015 & $\begin{array}{l}\text { Gold (1970), International Monetary } \\
\text { Fund, Monitoring of Fund } \\
\text { Arrangements (MONA) Database, } \\
\text { Joyce (2005), Killick (1995), Mody and } \\
\text { Saravia (2006). }\end{array}$ \\
\hline Note: the first program is 1952 : & & same \\
\hline Amount & 1952-2015 & same \\
\hline Type of program & 1952-2015 & same \\
\hline Beginning date & 1952-2015 & same \\
\hline End date & 1952-2015 & same \\
\hline Duration & 1952-2015 & $\begin{array}{l}\text { Author' calculation based on above } \\
\text { sources }\end{array}$ \\
\hline IMF membership date & $1945-2015$ & $\begin{array}{l}\text { International Monetary Fund, Financial } \\
\text { Position in the Fund, all member } \\
\text { countries }\end{array}$ \\
\hline IMF quota & $1945-2015$ & $\begin{array}{l}\text { International Monetary Fund, Financial } \\
\text { Position in the Fund, all member } \\
\text { countries }\end{array}$ \\
\hline IMF credit outstanding & $1970-2014$ & $\begin{array}{l}\text { IMF International Financial Statistics, } \\
\text { sum of GRA and loans outstanding }\end{array}$ \\
\hline $\begin{array}{l}\text { PPP-per capita GDP in US } \\
\text { dollars year=2009 }\end{array}$ & 2009 & $\begin{array}{l}\text { International Monetary Fund, World } \\
\text { Economic Outlook }\end{array}$ \\
\hline Nominal GDP & 1952-2015 & \\
\hline Public debt & $1952-2015$ & $\begin{array}{l}\text { Reinhart and Rogoff (2009), Reinhart } \\
\text { and Trebesch (2015), Abbas et al. } \\
\text { (2011) Historic Public Debt Database }\end{array}$ \\
\hline $\begin{array}{l}\text { External (public plus private) } \\
\text { debt }\end{array}$ & 1970-2015 & $\begin{array}{l}\text { Lane and Milesi-Ferretti dataset, IMF, } \\
\text { World Bank GDF/IDS }\end{array}$ \\
\hline World GDP & 1952-2015 & $\begin{array}{l}\text { International Monetary Fund, World } \\
\text { Economic Outlook }\end{array}$ \\
\hline World imports & 1952-2015 & $\begin{array}{l}\text { International Monetary Fund, World } \\
\text { Economic Outlook }\end{array}$ \\
\hline US CPI & 1952-2015 & Bureau of Labor Statistics \\
\hline Banking crises dates & $1945-2015$ & $\begin{array}{l}\text { Reinhart and Rogoff (2009) and } \\
\text { Reinhart (2015) }\end{array}$ \\
\hline Currency crises dates & 1945-2015 & $\begin{array}{l}\text { Reinhart and Rogoff (2009) and } \\
\text { Reinhart (2015) }\end{array}$ \\
\hline $\begin{array}{l}\text { Default on external debt } \\
\text { (private creditors) }\end{array}$ & 1945-2015 & $\begin{array}{l}\text { Reinhart and Rogoff (2009) and } \\
\text { Reinhart (2015) }\end{array}$ \\
\hline $\begin{array}{l}\text { Default/arrears on external } \\
\text { official creditors }\end{array}$ & $1975-2015$ & $\begin{array}{l}\text { Reinhart and Trebesch (2015), Beers } \\
\text { and Nadeau (2015), World Bank, } \\
\text { various. }\end{array}$ \\
\hline
\end{tabular}

